\title{
MATCH-SALSA - Multi-scale Atmospheric Transport and CHemistry model coupled to the SALSA aerosol microphysics model - Part 1: Model description and evaluation
}

\author{
C. Andersson ${ }^{1}$, R. Bergström ${ }^{1,2}$, C. Bennet ${ }^{1}$, L. Robertson ${ }^{1}$, M. Thomas ${ }^{1}$, H. Korhonen ${ }^{3, *}$, K. E. J. Lehtinen ${ }^{3,4}$, and \\ H. Kokkola ${ }^{3}$ \\ ${ }^{1}$ Swedish Meteorological and Hydrological Institute, 60176 Norrköping, Sweden \\ ${ }^{2}$ University of Gothenburg, Department of Chemistry and Molecular Biology, 41296 Gothenburg, Sweden \\ ${ }^{3}$ Finnish Meteorological Institute, Kuopio Unit, P.O. Box 1627, 70211 Kuopio, Finland \\ ${ }^{4}$ University of Eastern Finland, Department of Applied Physics, P.O. Box 1627, 70211 Kuopio, Finland \\ * now at: Finnish Meteorological Institute, Climate Research, P.O. Box 503, 00101 Helsinki, Finland
}

Correspondence to: C. Andersson (camilla.andersson@smhi.se)

Received: 28 March 2014 - Published in Geosci. Model Dev. Discuss.: 8 May 2014

Revised: 27 November 2014 - Accepted: 23 December 2014 - Published: 6 February 2015

\begin{abstract}
We have implemented the sectional aerosol dynamics model SALSA (Sectional Aerosol module for Large Scale Applications) in the European-scale chemistrytransport model MATCH (Multi-scale Atmospheric Transport and Chemistry). The new model is called MATCHSALSA. It includes aerosol microphysics, with several formulations for nucleation, wet scavenging and condensation.

The model reproduces observed higher particle number concentration (PNC) in central Europe and lower concentrations in remote regions. The modeled PNC size distribution peak occurs at the same or smaller particle size as the observed peak at four measurement sites spread across Europe. Total PNC is underestimated at northern and central European sites and accumulation-mode PNC is underestimated at all investigated sites. The low nucleation rate coefficient used in this study is an important reason for the underestimation. On the other hand, the model performs well for particle mass (including secondary inorganic aerosol components), while elemental and organic carbon concentrations are underestimated at many of the sites.

Further development is needed, primarily for treatment of secondary organic aerosol, in terms of biogenic emissions and chemical transformation. Updating the biogenic secondary organic aerosol (SOA) scheme will likely have a large impact on modeled $\mathrm{PM}_{2.5}$ and also affect the model performance for PNC through impacts on nucleation and condensation.
\end{abstract}

\section{Introduction}

Most aerosol properties relevant to climate are both size and chemical composition dependent. Thus, there is a need to resolve the size distributions of particle mass, number and chemical composition in climate models (e.g., Chen and Penner, 2005; Roesler and Penner, 2010). Aerosol particles also have adverse effects on human health (e.g., Pope and Dockery, 2006), which depend on particle size and chemical composition (WHO, 2013). In particular, ultrafine particles (with diameters of less than $100 \mathrm{~nm}$ ) may be important for their potential impacts on human health (e.g., Oberdörster et al., 1995; Peters et al., 1997; Knol et al., 2009), but there is still limited epidemiological evidence of their health effects (WHO, 2013). The ultrafine particles do not contribute significantly to the particle mass concentration (PM), but they constitute a large proportion of the particle number concentration (PNC). Aerosol microphysical processes need to be considered in greater detail in order to describe PNC and size distributions accurately (e.g., Adams and Seinfeld, 2002). This has led to an increased need for realistic treatment of aerosols in atmospheric models.

A number of chemical transport models (CTMs), which are used operationally for simulating atmospheric chemistry in Europe, were recently reviewed by Kukkonen et al. (2012). The aerosol descriptions in such types of models can be classified into three main categories: bulk schemes, modal schemes (Whitby and McMurry, 1997) and sectional 
schemes (Gelbard et al., 1980). In bulk schemes, typically the total mass concentration of particles, or the mass in a certain size interval, is modeled. LOTOS-EUROS (LOng Term Ozone Simulation - EURopean Operational Smog; Schaap et al., 2008), DEHM (Danish Eulerian Hemispheric Model; e.g. Frohn et al., 2002) and the EMEP MSC-W model (European Monitoring and Evaluation Programme Meteorological Synthesizing Centre - West; Simpson et al., 2012) are examples of bulk-type models.

In modal schemes, the aerosol size distribution is represented by a small number of modes, typically assuming lognormal size distribution for the modes. The description of new particle formation is limited in modal schemes. Modal schemes are computationally more expensive than simple bulk schemes, but less than the sectional approach, which is why they are commonly used in regional and global CTMs and climate models, e.g., the Regional Particulate Model (Binkowski and Shankar, 1995), CMAQ (Byun and Schere, 2006), CAM5-MAM3 (Liu et al., 2012), TM5 (Aan de Brugh et al., 2011), GLOMAP-mode (Mann et al., 2012), EMAC (Pringle et al., 2010), ECHAM5-HAM2 (Zhang et al., 2012), GISS-MATRIX (Bauer et al., 2008).

The sectional scheme, in which the size distribution is represented by a large number of discrete bins, is the most flexible and accurate choice - but computationally the most expensive. Many modern CTMs and global climate models (GCMs) include the sectional approach, e.g., PM-CAMx (Fountoukis et al., 2011), GLOMAP-bin (e.g., Reddington et al., 2011), ECHAM5-SALSA (Bergman et al., 2012) and GISS-TOMAS (Lee and Adams, 2010). PM-CAMx and GLOMAP-bin make the assumption of internally mixed particles, in GLOMAP described by 20 size bins, whereas GISSTOMAS includes externally mixed particles described by 30 size bins. Such a high size bin resolution is computationally demanding. GLOMAP uses prescribed monthly mean oxidant fields. Mann et al. (2014) compared the performance of 12 global aerosol microphysics models using modal and sectional approaches.

The standard version of the MATCH (Multi-scale Atmospheric Transport and Chemistry) model (Robertson et al., 1999; Andersson et al., 2007) uses a simple bulk scheme for treating aerosols, with four size bins for primary particles, without any aerosol dynamics treatment (except hygroscopic growth in some model versions), but with dry and wet deposition of primary particles dependent on particle size. The particle species considered in previous applications (e.g., Andersson et al., 2007, 2009) were primary anthropogenic elemental carbon (EC), organic carbon (OC) and non-carbonaceous particles, as well as secondary inorganic aerosol (sulfate, nitrate, ammonium) and sea-salt particles. Secondary organic aerosol was not included in the model. PNC formation and growth was not described. MATCH was adapted to assess anthropogenic ultrafine particles in an urban environment in a previous study (Gidhagen et al., 2005); seven monodisperse sizes were used and the aerosol dynam- ics considered water uptake, coagulation and dry deposition, but without inclusion of nucleation or condensation processes.

The MATCH model includes photo-chemistry for calculating oxidant fields that can be used for online coupling to oxidation of organics and sulfur compounds, resulting in a coupled photo-chemistry and aerosol dynamics description. Further, MATCH contains a number of advanced features, including data assimilation (Kahnert, 2008) and inverse modeling of aerosol optics of both surface observations and satellite data (Kahnert, 2009). These assimilation techniques are uncommon in models that include advanced aerosol dynamics.

We have implemented the sectional aerosol dynamics model SALSA (Sectional Aerosol module for Large Scale Applications; Kokkola et al., 2008) in the European-scale CTM MATCH (Robertson et al., 1999; Andersson et al., 2007). SALSA was chosen since it was developed to describe the PNC well; it includes several nucleation mechanisms and the sectional approach used in SALSA is an advantage for simulating new particle formation (e.g., Korhola et al., 2014). The coupling of SALSA to MATCH introduces a description of particle microphysics and aging in the model. New features include particle nucleation, condensation, coagulation and activation, leading to a description of the temporal evolution of the particle number size distribution in a number of bins, through the sectional approach. The model also describes the mixing state of the particles. The physical treatment of aerosol microphysics and the particle size distribution is described in Sect. 2.2; further details about the specific setup used in this study are given in Sect. 3. We discuss the performance of MATCH-SALSA in relation to other models in Sect. 4.

This paper presents the resulting new aerosol dynamics version of the MATCH model; the new model is called MATCH-SALSA. The model was detailed in a report from SMHI (Andersson et al., 2013), which is included as a supplement to this paper (Supplement A). In this paper, we highlight the main new features and present the results from evaluation tests. In a second paper (Andersson et al., 2015) results from various sensitivity tests will be presented. The aim of MATCH-SALSA is to describe particle mass and number concentrations, and particle size distribution on the European scale. The new model features - inclusion of sectional descriptions of aerosol microphysics and particle number size distributions - are developed with the aim to couple the MATCH-SALSA model to climate models and radiative transfer calculations; the new model can also be utilized for the estimation of human exposure to particles of different sizes.

\section{Description of MATCH-SALSA}

The layout of MATCH-SALSA is illustrated in Fig. 1. After initializations are completed, the model integrates starting 


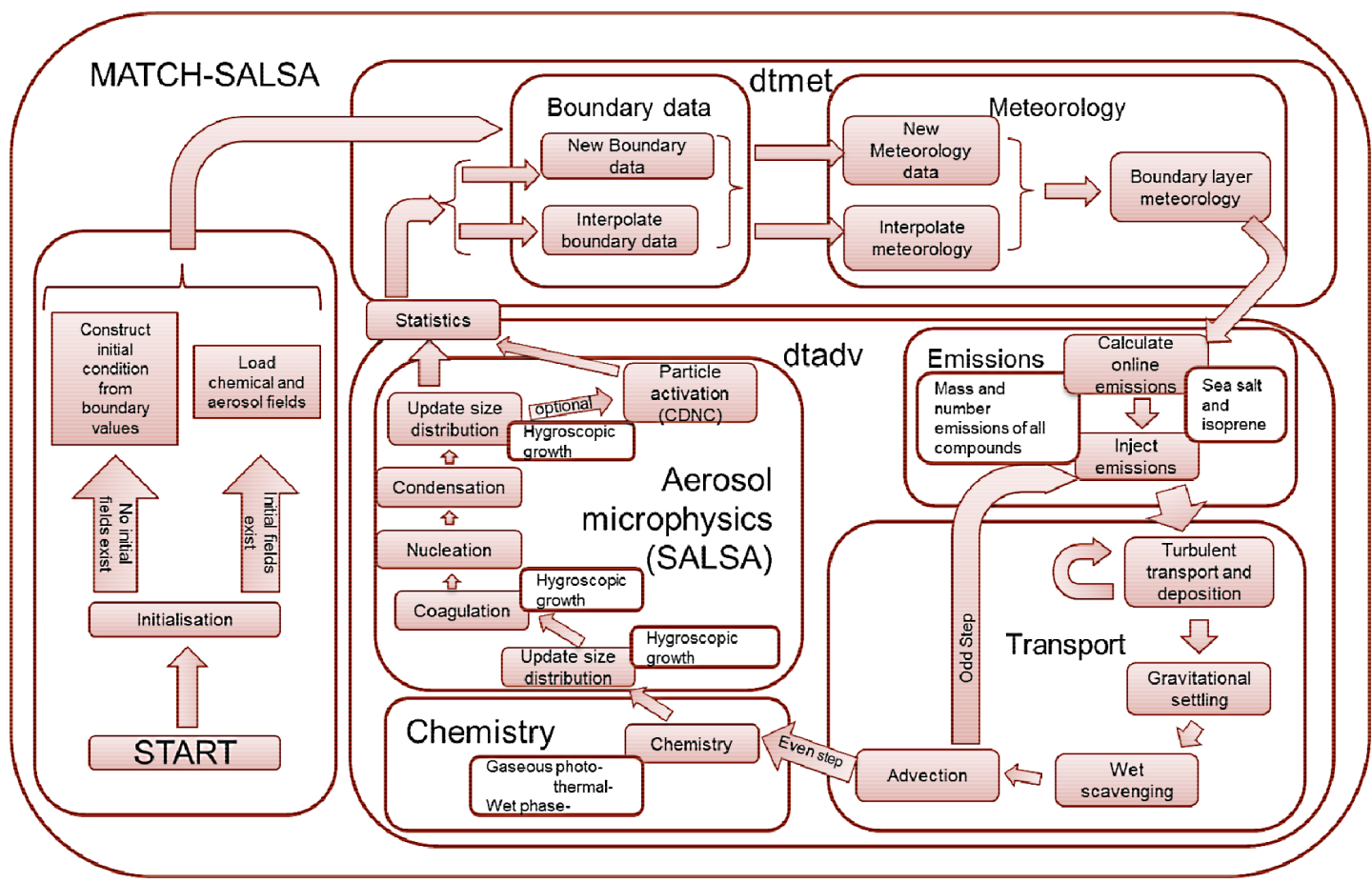

Figure 1. Model layout and time stepping in MATCH-SALSA.

with reading or interpolation of weather data, reading emissions and setting lateral and top boundary concentrations of the chemical species. After this, the emissions are injected and model transport fluxes are calculated with the internal sub-stepping time steps. Subsequently, the model gas-phase and wet-phase chemistry, aerosol microphysics and cloud droplet number concentrations are calculated. Meteorological data are read at regular intervals, typically every 3 or 6 hours. Boundary conditions may be updated at compounddependent time intervals.

Natural and anthropogenic emissions are included in the model. Sea salt and isoprene emissions are calculated online, whereas anthropogenic and other emissions (volcanic sulfur, marine dimethyl sufide (DMS) and biogenic monoterpenes) are given as input data to the model in the setup used in the present study. All primary particle components are emitted both as mass and number. Sea-salt emissions are modeled as described by Foltescu et al. (2005) but modified to allow arbitrary size bins. For the smallest bins (diameters of $\leq 1 \mu \mathrm{m}$ ), the description by Mårtensson et al. (2003) was used; for larger sizes the sea-salt generation function was taken from Monahan et al. (1986). Biogenic emissions of isoprene are calculated using the E-94 isoprene emission methodology proposed by Simpson et al. (1995). Emissions from wildfires and agricultural burning are not included in the present version of the model.

The transport model includes advective and turbulent transport. Particle number and mass are transported inde- pendently in MATCH-SALSA. The transport scheme is described in detail in Robertson et al. (1999).

\subsection{Chemistry}

The original MATCH photochemistry scheme (Langner et al., 1998) was, to a large extent, based on the EMEP MSCW (European Monitoring and Evaluation Programme Meteorological Synthesizing Centre - West) scheme (Simpson, 1992; Simpson et al., 1993), but with an alternative treatment of isoprene chemistry, using an adapted version of the Carter one-product mechanism (Carter, 1996; Langner et al., 1998). A simplified mixture of a dozen representative compounds ("lumped molecules") was used to model all organic molecules emitted to the atmosphere (e.g., $o$-xylene represents all emitted aromatic species).

The gas-phase chemistry scheme in MATCH has remained mostly the same since 1998, but a number of reaction rates have been updated, taking into account new recommendations from the International Union of Pure and Applied Chemistry (IUPAC; Atkinson et al., 2006) and the Master Chemical Mechanism, MCM v3 (Jenkin et al., 1997; Saunders et al., 2003, via http://mcm.leeds.ac.uk/MCM); a few new gas-phase components have also been added to the scheme. The revision of the MATCH chemistry scheme was based closely on the updates done in the EMEP MSCW model, during 2008-2009, as documented by Simpson et al. (2012); the updated gas-phase reaction scheme in MATCH is nearly identical to the EMEP MSC-W Em- 
Chem09 scheme of Simpson et al. (2012), but, for isoprene, the scheme from Langner et al. (1998) is retained (with some reaction rates updated to new recommended values from the IUPAC (Atkinson et al., 2006), see Supplement B).

In addition to gas-phase chemistry, aqueous-phase oxidation of $\mathrm{SO}_{2}$ in cloud water (based on Berge, 1992) and a few heterogeneous reactions for nitrogen compounds are included in the model. For MATCH-SALSA some further modifications related to particle formation have been made and the scheme used in the present work consists of ca. 140 thermal, wet and photolysis reactions, including ca. 60 different chemical species.

The chemistry code includes a simple scheme for secondary organic aerosol (SOA) formation from biogenic monoterpene emissions; $\alpha$-pinene is used as a surrogate for all monoterpenes. In the present study, we assume rapid formation of condensable SOA after gas-phase oxidation of $\alpha$ pinene (by $\mathrm{O}_{3}, \mathrm{OH}$ or $\mathrm{NO}_{3}$; oxidation rates are based on MCM v3.2, http://mcm.leeds.ac.uk/MCM); we assumed that all oxidation paths for $\alpha$-pinene produce low-volatility SOAforming compounds, with $10 \%$ (mass-based) yield. These compounds are included in the condensation scheme for organic compounds in SALSA. The SOA yield used here for $\alpha$-pinene is relatively high compared to some reported SOA yields for this monoterpene in smog chamber experiments (e.g., Mentel et al. (2009) found about $5 \%$ yield). However, recent findings by Ehn et al. (2014) regarding formation of extremely low-volatility organic compounds from ozonolysis of $\alpha$-pinene indicate that SOA yields from this process may be higher than $10 \%$ above forest canopies. We also note that there are recent studies that indicate that SOA yields based on smog chamber studies may be underestimated by up to a factor of 4, due to wall losses of gas-phase semivolatile organic (Kokkola et al., 2014; Zhang et al., 2014). Note that the simplified biogenic secondary organic aerosol (BSOA) "scheme" used in the present study is included to test the organic-aerosol parts of MATCH-SALSA, with minimal changes to the standard photochemistry scheme; it is not expected to model BSOA formation in a very realistic way compared to real-world conditions, but, given the high uncertainties in monoterpene emissions and the neglect of other BSOA-forming emissions, it was considered a reasonable approach for the development phase of MATCH-SALSA.

The chemical equations are solved prior to SALSA. There is no internal sub-stepping between the chemistry and SALSA (cf. Fig. 1). For a detailed description of the MATCH chemistry scheme, including a full list of the reactions and reaction rates, see Supplement B.

\subsection{Aerosol microphysics}

The SALSA model was designed to obtain a balance between computational efficiency and numerical accuracy. This was reached by keeping the number of tracer variables low, by using a relatively coarse particle size resolution, and includ- ing only the relevant chemical compounds in different particle size ranges (see Kokkola et al., 2008). The size resolution varies across the size spectrum, with higher resolution for particles that are crucial in cloud activation and for aerosol radiative properties.

Aerosol number and mass concentrations are described by three size ranges, divided into size bins with equidistant distribution of the bins on the lognormal scale. The number of bins in each subrange and the size limits of the subranges are flexible. The level of mixing differs between the subranges:

1. In the smallest subrange, all particles are internally mixed.

2. In the second subrange, there are two parallel externally mixed size bins for each size. In this subrange, we assume that soluble compounds (sulfate, sea salt and soluble organics) are emitted to so-called soluble bins whereas insoluble compounds (black carbon, mineral dust and insoluble organics) are emitted to the insoluble bins.

3. In the largest subrange, there are three externally mixed size bins: (1) soluble, into which the above-mentioned soluble compounds are emitted, (2) cloud active insoluble particles, which are mainly composed of insoluble compounds, but which have enough soluble material to activate as cloud droplets, and (3) freshly emitted insoluble range, into which insoluble compounds are emitted.

In addition, the chemical compounds that are treated in each size range are chosen depending on the compounds that are relevant to that size of particles in the atmosphere (for details, see Kokkola et al., 2008):

1. The first size range (nucleation and Aitken modes) includes sulfate $\left(\mathrm{SO}_{4}^{2-}\right)$ and $\mathrm{OC}$.

2. The second (accumulation-mode) size range includes $\mathrm{SO}_{4}^{2-}, \mathrm{EC}, \mathrm{OC}$, sea salt $(\mathrm{NaCl})$ and mineral dust in two externally mixed parallel size bins for each size section.

3. The third (coarse-mode) size range also includes $\mathrm{SO}_{4}^{2-}$, $\mathrm{EC}, \mathrm{OC}$, sea salt $(\mathrm{NaCl})$ and mineral dust in three externally mixed particle types: sea salt, "insoluble dust" and "soluble dust"; all water soluble compounds, including $\mathrm{SO}_{4}^{2-}$ and $\mathrm{OC}$, are combined in the soluble dust type.

Note that EC is not included in the Aitken mode, which is a shortcoming of MATCH-SALSA. The reason for this choice in SALSA was to reduce the CPU burden.

The hygroscopicity of the aerosol is calculated using the Zdanowskii-Stokes-Robinson method (Jacobson, 2002). At the end of each microphysical time step, the size distribution is updated to take into account the growth of particles due to dynamic and chemical transformation processes. 
Nitrate in coarse-mode particles is treated separately as a simple tracer compound. Other particulate nitrogen species are described by a simplified chemistry scheme (see Supplement B), currently handled outside SALSA i.e., ammonium salts (e.g., ammonium nitrate) are not taken into account in the modeling of the aerosol microphysical processes. After the aerosol microphysical processes have taken place, ammonium bound to sulfate is distributed according to the size distribution of particulate sulfate and ammonium nitrate is distributed according to the available aerosol surface area. However, this condensation of ammonium and nitrate does not affect the particle radius in the model, and thus they do not influence the shape of the size distribution. A possible consequence of the simplified treatment can be underestimation of condensational growth, which may cause overestimation of nucleation, due to a too-small condensational sink for the nucleation-mode particles. The lack of ammonium nitrate condensation in the aerosol microphysics could cause underestimation of cloud droplet number concentration (CDNC).

In this study nucleation is simulated through an activationtype nucleation formulation (Kulmala et al., 2006; Riipinen et al., 2007) and the formation rate of $3 \mathrm{~nm}$ particles (J3) is calculated according to Lehtinen et al. (2007). Nucleation is solved concurrently with condensation, using the methodology of Jacobson (2002); this takes into account the competition of nucleation and condensation in the mass transfer of volatile species between gas and particle phase. The MATCH-SALSA model also includes other nucleation schemes, for example binary nucleation (Vehkamäki et al., 2002), ternary nucleation (Napari et al., 2002a, b) and activation of both $\mathrm{H}_{2} \mathrm{SO}_{4}$ and organic vapors (Paasonen et al., 2010; Supplement C). Tests of these alternative nucleation schemes will be presented in the companion paper (Andersson et al., 2015).

The scheme used for gas-to-particle transformation is the analytical predictor of condensation scheme, with saturation vapor pressure set to zero (Jacobson, 1997). The scheme solves condensation and evaporation of semi-volatile compounds over a discrete time step. It is very well suited for large-scale atmospheric models, such as MATCH, since it requires no iteration, it is mass conserving, and it has been shown to be accurate over a time step length of $7200 \mathrm{~s}$ when condensation is the only active process (Jacobson, 2005).

Coagulation is described using a semi-implicit scheme (Jacobson, 1994). Similarly to the condensation scheme, a semiimplicit coagulation scheme does not require iteration and it is mass conserving. Since coagulation is the (computationally) most time-consuming microphysical process, it is neglected between aerosol pairs for which the coagulation efficiency is low. The detailed list of selected collision pairs accounted for in the coagulation routine is given in Kokkola et al. (2008).

Further details of the SALSA model are given by Kokkola et al. (2008) and Bergman et al. (2012).

\subsection{Deposition}

Dry deposition of trace gases is calculated with a simple resistance approach (Chamberlain and Chadwick, 1965), which depends on land use and season. Wet scavenging of most gaseous species is proportional to the precipitation intensity. For ozone, hydrogen peroxide and sulfur dioxide, incloud scavenging is calculated assuming Henry's law equilibrium; sub-cloud scavenging is neglected for these species. For ozone, sub-cloud scavenging is likely to be negligible; $\mathrm{O}_{3}$ has a very low solubility in water and wet deposition is not an important sink process for this species. For $\mathrm{SO}_{2}$, the omission of sub-cloud scavenging likely leads to a slight underestimation of the wet-deposition losses; however, $\mathrm{SO}_{2}$ also has a relatively low solubility and a modeling study of wet scavenging of sulfur (Berge, 1993) found that subcloud scavenging by precipitation was small (only about $1 \%$ of the total S-deposition was due to sub-cloud scavenging). The absence of sub-cloud scavenging for $\mathrm{H}_{2} \mathrm{O}_{2}$ probably leads to a substantial underestimation of wet deposition for this compound. In recent MATCH model simualtions that included sub-cloud scavenging of $\mathrm{H}_{2} \mathrm{O}_{2}$, it was found that sub-cloud scavenging contributed about $20-40 \%$ to the total wet deposition of $\mathrm{H}_{2} \mathrm{O}_{2}$. Wet and dry deposition of gases in the MATCH model is described in detail by Andersson et al. (2007).

Particle dry deposition (including the effects of hygroscopic growth) is calculated using a scheme based on Zhang et al. (2001), adapted to a smaller set of land use classes (water, forest, low vegetation and vegetation-free land areas). More details regarding the dry deposition of particle species are given in Supplement A.

Particles are wet deposited through in-cloud and sub-cloud scavenging. The in-cloud scavenging depends on the fraction of cloud water (or ice) that is precipitated in each grid box, the fraction of the box that is cloudy, the concentration of particles and the fraction of particles in each particle size bin that are inside the cloud droplets. MATCH-SALSA includes a simplified scheme, based on Seinfeld and Pandis (1997), to estimate the fraction of particles that are activated as cloud droplets (and thus are located inside the droplets) - in-cloud particles larger than $80 \mathrm{~nm}$ in diameter are considered activated as cloud droplets. This simplified description is used in the present study.

A more advanced (and CPU-time-consuming) formulation for cloud activation is also implemented in MATCH-SALSA. The model can be run coupled to an online cloud activation model that computes CDNC based on the prognostic parameterization scheme of Abdul-Razzak and Ghan (2002). The number of activated particles in each size bin is determined by the particle size distribution, their number concentration and chemical composition, as well as the updraft velocity and the maximum supersaturation of the air parcel. Running the model with particle activation is optional. Optionally, the resulting activated particle fraction in each size bin can be used 
for the calculation of in-cloud scavenging of particles. In this formulation, the activated fraction of each particle class is calculated in each time step for each grid point. The online cloud-activation scheme was not used in the present study, but in Supplement A it is compared to the simplified scheme used here.

The sub-cloud scavenging in the model is treated in a similar way as by Dana and Hales (1976). In MATCH-SALSA, a simplified approach is used where a monodisperse washout coefficient is calculated for each particle bin, and a standard rain drop spectrum ${ }^{1}$ is assumed for all precipitation. The washout coefficient (i.e., the fraction of a species that is removed by precipitation below clouds) depends on precipitation amount and takes into account particle collection by Brownian diffusion, inertial impaction and interception. The total wet deposition is the sum of the in-cloud and sub-cloud scavenging.

Further details on the wet scavenging of particles are given in Supplement A and in the companion paper Andersson et al. (2015).

\section{Model setup}

In this section we describe the setup of the simulation used to evaluate MATCH-SALSA in Sect. 4.

Meteorological data are input at regular time intervals; here we used 3-hourly fields from the HIRLAM (HiResolution Limited-Area Model; Undén et al., 2002) weather forecast model. The meteorological data are interpolated to hourly resolution. The model domain covers Europe with a spatial resolution of ca. $44 \mathrm{~km}$. The lowest model level is ca. $60 \mathrm{~m}$ thick, and, in total, 22 vertical levels are used; the top level is at about $5 \mathrm{~km}$ height. The vertical structure of MATCH-SALSA is the same as in the meteorological model, in this case hybrid $(\eta)$ coordinates, with shallow terrain following layers close to the ground and thicker pressure levels higher up.

For the aerosol size distribution, the following settings were used (see Fig. 2): the first subrange covered the diameter interval 3-50 nm, with three lognormally distributed size bins; the second subrange covered the diameter interval 50$700 \mathrm{~nm}$, with four bins each for soluble and insoluble particle types; the third subrange covered the diameter size range of $700 \mathrm{~nm}-10 \mu \mathrm{m}$, with three size bins for each of the following three particle types: sea salt, soluble particles and insoluble particles.

The top and lateral boundary concentrations of gaseous and particle species, including seasonal variation for some species, were set as described in Andersson et al. (2007). However, boundary concentrations of particulate organic matter $(\mathrm{OM})$ on the southern, western and northern bound-

\footnotetext{
${ }^{1}$ A representative frontal rain spectrum is used, $R_{g}=0.02 \mathrm{~cm}$, $\Sigma_{g}=1.86$ (Dana and Hales, 1976).
}

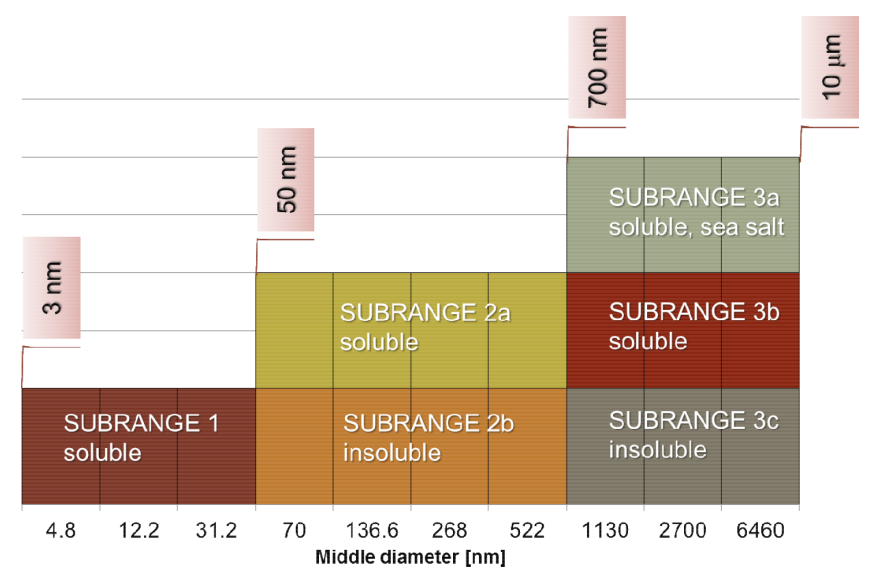

Figure 2. Aerosol division into bins in the three SALSA subranges in the base case setup of MATCH-SALSA.

ary were set based on marine OM measurements (O'Dowd et al., 2004).

In the present study, biogenic emissions of monoterpenes (MT) were based on monthly emissions of MT taken from the EMEP MSC-W model (Bergström et al., 2012; Simpson et al., 2012). The biogenic volatile organic compound (BVOC) emissions are highly uncertain. With four different chemical transport models, Langner et al. (2012) predicted European isoprene emissions within about a factor of 5 ; we do not expect the uncertainty in the monoterpene emissions to be lower than for isoprene. Considering the large uncertainties, emissions tests with varying terpene emissions were performed; decreased underestimation in March and July 2007 for PNC and accumulation-mode PNC and improved temporal variation in March 2007 were found at the four measurement sites (see Supplement A) when using 3 times larger emissions than those taken from the EMEP MSC-W model. For this reason, the MT emissions in the base case simulations in the present study were chosen to be 3 times higher than the corresponding emissions in the EMEP MSC-W model. We stress once more that the biogenic SOA description in the present MATCH-SALSA model setup is incomplete and simplified - the aim is to test the first versions of MATCH-SALSA without introducing a complex and uncertain SOA scheme at the same time as introducing the aerosol dynamics module. The fact that model performance improved when the MT emissions were tripled should not be interpreted as an indication that the MT emissions are underestimated in the EMEP MSC-W model. A number of BVOC emissions are missing in the MATCH-SALSA model (e.g., sesquiterpenes and other VOCs emitted by plants subject to stress; e.g., Bergström et al., 2014). We also miss some other potentially important OA sources, such as wild fires (and other open burning), anthropogenic secondary OA and multigenerational aging of organic compounds in the atmosphere. The increased BVOC emissions in the model may lead to improved model results by compensating for other missing 

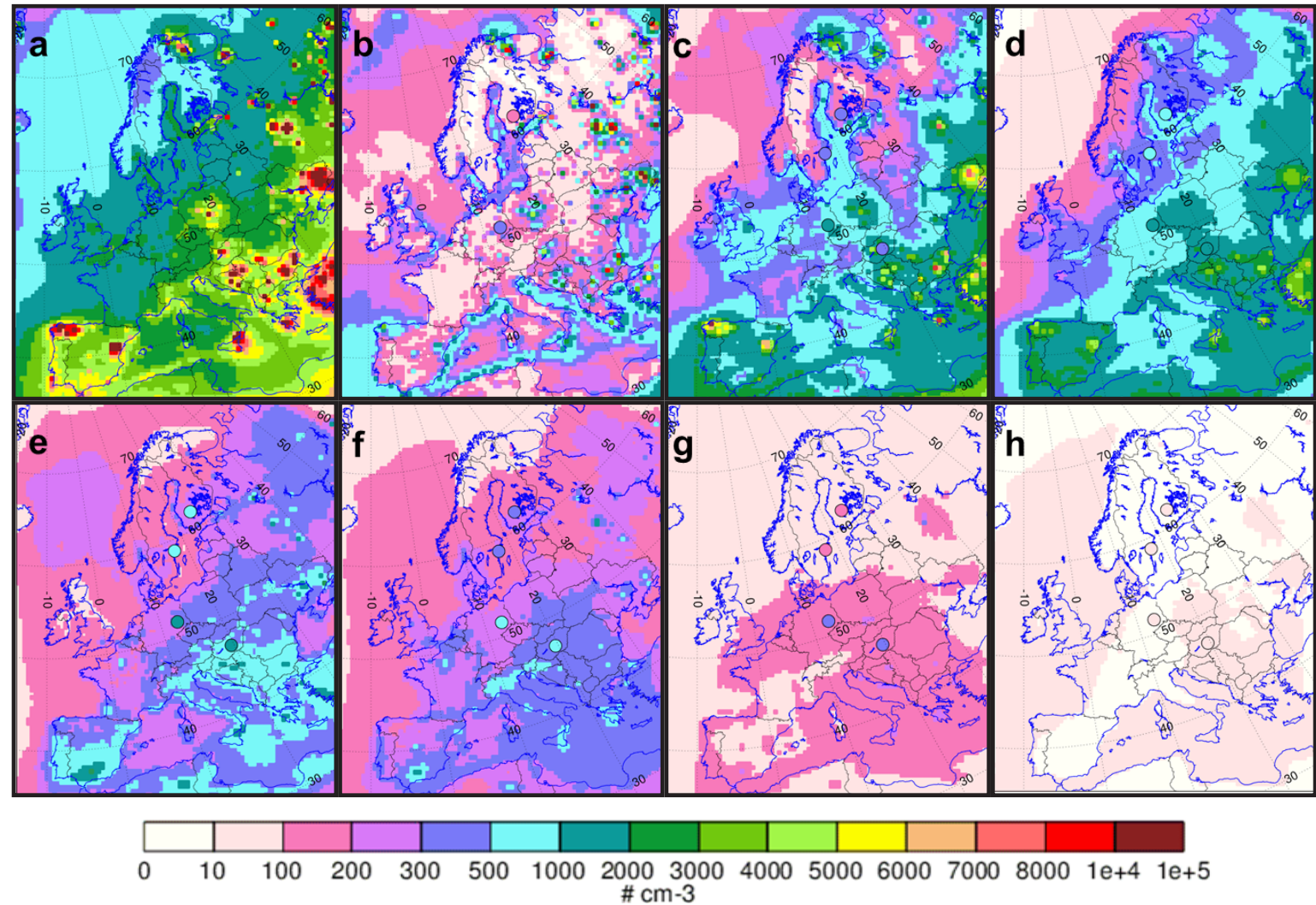

Figure 3. Calculated annual mean (2007) particle number concentration (PNC) in Europe. Total PNC (sum of all sizes) (a), PNC in size bins $\mathrm{PNC}_{3<d<7} \mathrm{~nm}(\mathbf{b}), \mathrm{PNC}_{7<d<20 \mathrm{~nm}}(\mathbf{c}), \mathrm{PNC}_{20<d<50 \mathrm{~nm}}$ (d), $\mathrm{PNC}_{50<d<98 \mathrm{~nm}}(\mathbf{e}), \mathrm{PNC}_{98<d<192 \mathrm{~nm}}(\mathbf{f}), \mathrm{PNC}_{192<d<360 \mathrm{~nm}}(\mathbf{g})$,

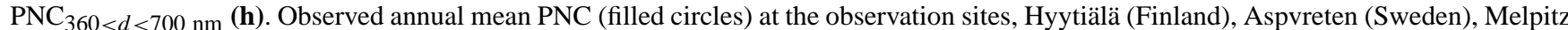
(Germany) and K-puszta (Hungary), when observed numbers exist in the indicated interval. Units in $\mathrm{cm}^{-3}$.

sources of OA or for too-low SOA yields from BVOC oxidation.

The anthropogenic emissions of gases and primary aerosols are taken from the TNO-MACC (Monitoring the Atmospheric Composition and Climate) emission inventory (Kuenen et al., 2011; Pouliot et al., 2012; see also the MACC project web page http://www.gmes-atmosphere.eu/). The TNO-MACC emissions are given as annual totals. Seasonal, weekday and diurnal variations of the emissions are based on results from the GENEMIS project (http://genemis. ier.uni-stuttgart.de/; Friedrich and Reis, 2004).

The particle emissions of $\mathrm{EC}$ and $\mathrm{OM}^{2}$ are distributed over different particle sizes according to sector resolved mass size distributions described by Visschedijk et al. (2009). Details about the size distributions are given in Supplement A (Table S4, p. 16). Emissions from most Selected Nomenclature for Sources of Air Pollution (SNAP) sectors are described by unimodal distributions, while emission from two sectors (international shipping and SNAP sector 4: production processes) are described by bimodal distributions.

\footnotetext{
${ }^{2} \mathrm{OM}$ emissions are assumed to be distributed over different particle sizes in the same way as OC.
}

The emissions of oxidized sulfur $\left(\mathrm{SO}_{\mathrm{x}}\right)$ were split into $99 \% \mathrm{SO}_{2}$ and $1 \% \mathrm{H}_{2} \mathrm{SO}_{4}$. The split is intended to account for sub-grid-scale processes of gas-phase transformation and gas-to-particle partitioning. The distribution of $\mathrm{SO}_{\mathrm{x}}$ emissions between $\mathrm{SO}_{2}$ and more oxidized compounds is discussed in Spracklen et al. (2005b) - the fraction of $\mathrm{SO}_{2}$ increases with grid resolution and it is typically set to between 95 and $100 \%$ in European-scale models. The assumed fractions have large uncertainties and it is not clear from the literature how to optimally partition $\mathrm{SO}_{\mathrm{x}}$ emissions between $\mathrm{SO}_{2}(\mathrm{~g}), \mathrm{H}_{2} \mathrm{SO}_{4}(\mathrm{~g})$ and particulate sulfate in modeling studies. The best distribution depends on model resolution (Spracklen et al., 2005b). Lee et al. (2013) have shown that the uncertainties in the sub-grid production of sulfate particles in plumes are more important for cloud condensation nuclei $(\mathrm{CCN})$ uncertainty than the uncertainties in the total anthropogenic $\mathrm{SO}_{2}$ emissions. Since we expect that the choice of distribution of $\mathrm{SO}_{\mathrm{x}}$ emissions has a large impact on the model results, we investigate this further in a companion paper (Andersson et al., 2015). The size distribution

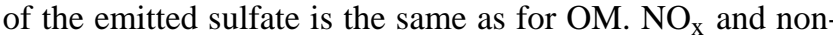


methane volatile organic compound emissions were handled in the same way as in Andersson et al. (2007).

\section{Evaluation of MATCH-SALSA}

In this section we compare our model results to observations at a number of measurement sites throughout Europe. The evaluated model results are extracted from the lowest model level. The statistical measures used are defined in Supplement A. We evaluate the PNC, both in terms of total number concentration, accumulation-mode number concentration and temporal and spatial distribution. We also evaluate the particle mass, including speciation of secondary inorganic aerosol, EC and OC.

\subsection{Measurement data}

Most measurement data were extracted from EBAS (http: //ebas.nilu.no). Details of the stations used in the evaluation of particle number size distribution, $\mathrm{PM}_{1}, \mathrm{PM}_{2.5}$, $\mathrm{EC}$ and $\mathrm{OC}$ are given in Supplement A (Table 5). The secondary inorganic aerosol (SIA) components (nitrate, sulfate and ammonium) were evaluated against available measurements in the EMEP network for 2007 (http://www.emep.int).

For evaluation of PNC, four stations from EBAS were chosen to represent different parts of Europe, all classified as rural background sites. Two of the measurement sites, Melpitz (in eastern Germany) and K-puszta (in central Hungary), are relatively close to regions with large emissions. Hyytiälä (inland southern Finland) and Aspvreten (ca. $70 \mathrm{~km}$ southwest of Stockholm, in southeastern Sweden) were chosen as regional background stations occasionally impacted by aged particles due to transport from large emission sources in $\mathrm{Eu}-$ rope.

\subsection{Model evaluation of PNC}

Figure 3 shows the modeled annual mean PNC in Europe; both total PNC (Fig. 3a) and the PNC in the different model size bins up to $700 \mathrm{~nm}$ are shown (Fig. 3b-g). Corresponding measured annual mean PNC values at the four measurement sites are also displayed in circles for particle sizes where measurements are available.

The largest modeled total PNC values (Fig. 3a) are found in areas with high $\mathrm{SO}_{\mathrm{x}}$ emissions (e.g., areas around large point sources in Spain, Poland, southeastern Europe, Ukraine, Russia and the area around Mount Etna; as well as along shipping routes around the Iberian Peninsula and the Gibraltar Strait). These results are in line with other model studies (e.g., Yu and Luo, 2009; Spracklen et al., 2010; Ahlm et al., 2013).

Most of the total PNC in the model resides in the Aitken-mode bins (particle diameters of 7-20 and 20-50 nm; Fig. $3 \mathrm{c}$ and d). The highest PNC values in the smallest bin (Fig. 3b), indicating recent nucleation, are found in Russia and Ukraine. Increased values in this bin are also seen along shipping lanes; the modeled high nucleation in marine areas is not in agreement with observations (Heintzenberg et al., 2004). Metzger et al. (2010) found similar nucleation over oceanic regions with large sulfur emissions when traditional activation-type nucleation mechanisms were used; their results, with a new organic activation mechanism, captured the observed lack of nucleation in marine areas, indicating that organic molecules may have a critical role in the nucleation.

The Aitken-mode PNC pattern (Fig. 3c and d) is similar to the total PNC distribution (Fig. 3a). The highest concentrations are found in areas in Spain, Turkey, the Balkan Peninsula, and northwestern Russia, and around the volcano Etna. The highest accumulation mode (50-700 nm) PNC values (Fig. 3e-h) are found in southern Europe. This is partly due to relatively large emissions of primary fine particles and gaseous $\mathrm{SO}_{\mathrm{x}}$, and partly due to less precipitation in southern Europe, compared to the north and west, allowing accumulation-mode particles to reside longer in the atmosphere.

We evaluate the model performance (see Figs. 4-6) in terms of total and accumulation-mode particle number concentration (PNC and $\mathrm{PNC}_{\mathrm{a}}$, respectively) against observations at the four European surface sites. Due to seasonal differences in emissions and atmospheric processes, we separate performance during summer half-years (April-September) from winter half-years (January-March, October-December). For example, residential biomass burning emissions are much higher during winter than during summer, while biogenic VOC emissions are largest during summer. Both these sources are associated with large uncertainties regarding the emissions and modeling. It should be noted that the size ranges for $\mathrm{PNC}$ and $\mathrm{PNC}_{\mathrm{a}}$ vary between the stations depending on the measurement interval.

\subsubsection{Spatial distribution}

Modeled total PNC shows moderate to poor agreement with the observations (Fig. 4a). At most sites, the deviation between observed and modeled mean is large both in summer and winter, and the correlation coefficients for daily mean PNC values are low ( $r$ values range from 0.05 to 0.66 ).

The model captures the general observed features of lower total and accumulation-mode PNC in the northern and northwestern parts of Europe (Fig. 3). Aspvreten and Hyytiälä have the lowest modeled and observed PNC values (Fig. 4a). However, looking in more detail at the stations (Fig. 4) there are some discrepancies. Melpitz clearly has the highest observed total PNC (during both winter and summer; Fig. 4a); the model severely underestimates the PNC at Melpitz and predicts much higher total PNC at K-puszta than at Melpitz. The highest observed accumulation-mode PNC values are found at K-puszta and Melpitz (the PNC values are at similar levels for both seasons and both sites; Fig. 4b); just as for to- 

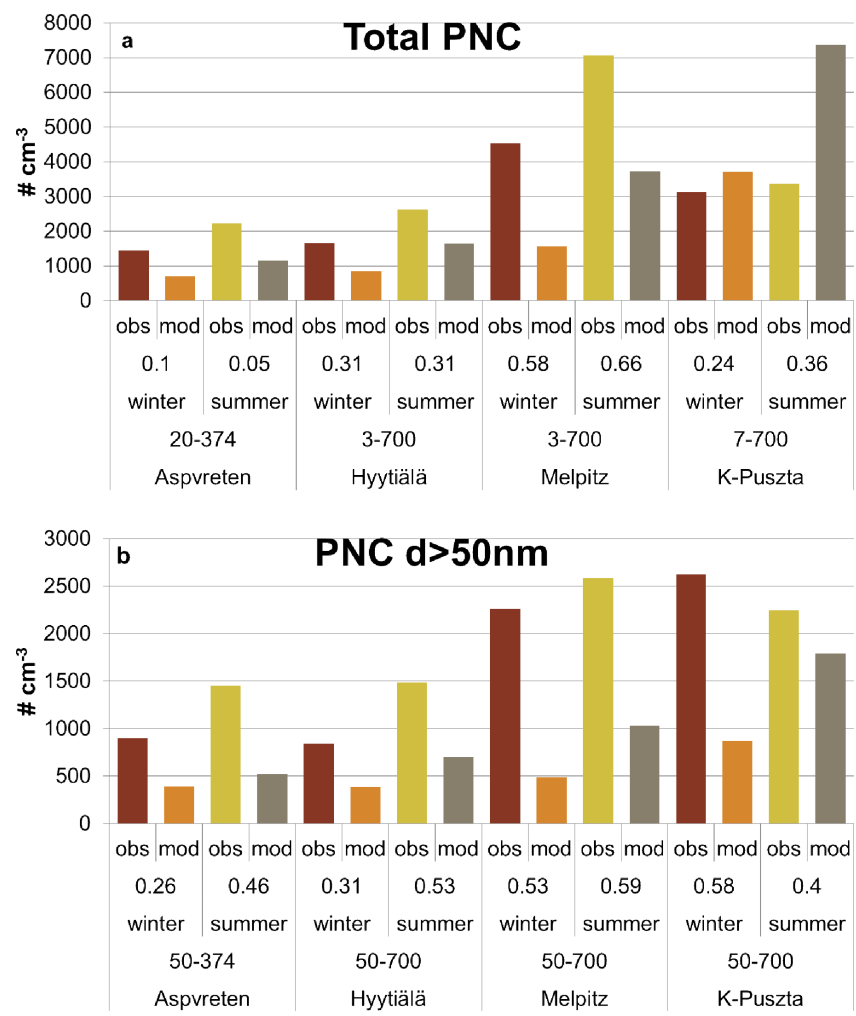

Figure 4. Mean particle number concentration (PNC) during winter (January-March, October-December) and summer (AprilSeptember) half-years at four sites in Europe. Top panel (a): mean observed and modeled total PNC. Bottom panel (b): mean observed and modeled PNC in the accumulation mode. The interval above the site name indicates the particle size interval $(\mathrm{nm})$. The number above the season shows the (Pearson) correlation coefficient $(r)$ of daily mean PNC. Note that the size intervals differ between the stations: the same size interval is used for both modeled and observed values at each site. Units in $\mathrm{cm}^{-3}$.

tal PNC, the model predicts much higher accumulation-mode PNC at K-puszta than at Melpitz.

Thus, the spatial distribution of PNC in the model is not in agreement with the observations. There may be many reasons for this. One important reason for the high modeled total $\mathrm{PNC}$ at K-puszta is a high rate of nucleation (Fig. 5c), which is caused by the large emissions of $\mathrm{SO}_{\mathrm{x}}$ in the area. For the other three northern and central European sites, there are underestimations in all size ranges. This may be due to a tooweak nucleation rate, too-efficient wet scavenging or a combination of various problems. For the Aitken and accumulation modes, the problem can also be due to underestimated primary emissions. The underestimation in the nucleation mode implies either a low-biased nucleation mechanism, a too-efficient removal (deposition) or underestimated precursor emissions. Further, EC is not included in the Aitken mode in the model. This leads to underestimated total particle number concentration (in the Aitken mode and subsequently in larger sizes as well).

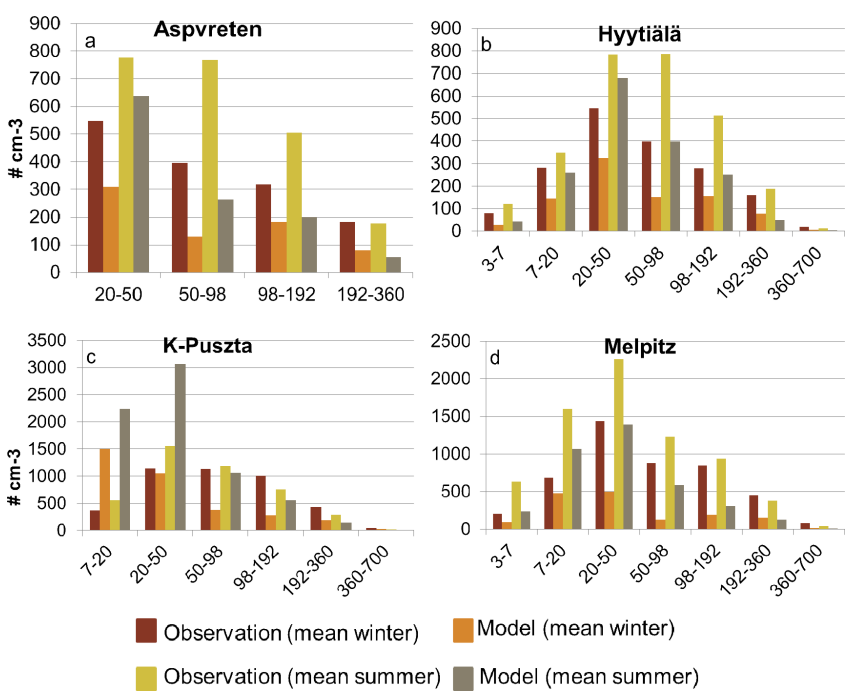

Figure 5. Modeled and measured winter (January-March, OctoberDecember) and summer (April-September) half-year mean particle number concentration size distribution at four measurement sites in Europe during 2007. Units in $\mathrm{cm}^{-3}$.

Spracklen et al. (2010) investigated the impact of different nucleation mechanisms, including the impact of using different nucleation rate coefficients in the activation mechanism. They chose to investigate three rate coefficients, $A=$ $2 \times 10^{-7} \mathrm{~s}^{-1}, 2 \times 10^{-6} \mathrm{~s}^{-1}$ and $2 \times 10^{-5} \mathrm{~s}^{-1}$, for which they evaluated the bias to global observations in the free troposphere, and the marine and continental boundary layers. In the continental boundary layer the two lowest nucleation rate coefficients resulted in mean underestimations of -48 and $-29 \%$ respectively, whereas the highest rate resulted in a slight overestimation, on average, of $12 \%$. The nucleation rate coefficient used in MATCH-SALSA in the present study is near the lower end of the interval $\left(A=7.3 \times 10^{-7} \mathrm{~s}^{-1}\right)$, which may explain our underestimation of nucleation at the central and northern sites. In fact, the nucleation rate coefficient in the activation scheme should be site and time dependent in the European boundary layer (e.g., Sihto et al., 2006; Riipinen et al., 2007): observations of this coefficient vary by $\sim 4-5$ orders of magnitude for different European measurement sites, ranging from $3.3 \times 10^{-8}$ to $3.5 \times 10^{-4} \mathrm{~s}^{-1}$ (Riipinen et al., 2007). Thus, a more advanced description of the nucleation, e.g., time-varying and space-varying rate coefficients, should be included in MATCH-SALSA.

Organic nucleation is not included as a nucleation process in the evaluated base case simulation, resulting in a possible underestimation of nucleation in areas with high BVOC concentrations and possibly overestimated nucleation in regions with low concentrations of organic aerosol precursors (similar to the overestimated nucleation in the model in oceanic high-SO $\mathrm{S}_{\mathrm{x}}$ regions, discussed above). This may also be an explanation for the overestimated nucleation at K-puszta. Sensitivity tests including organic nucleation will be discussed 

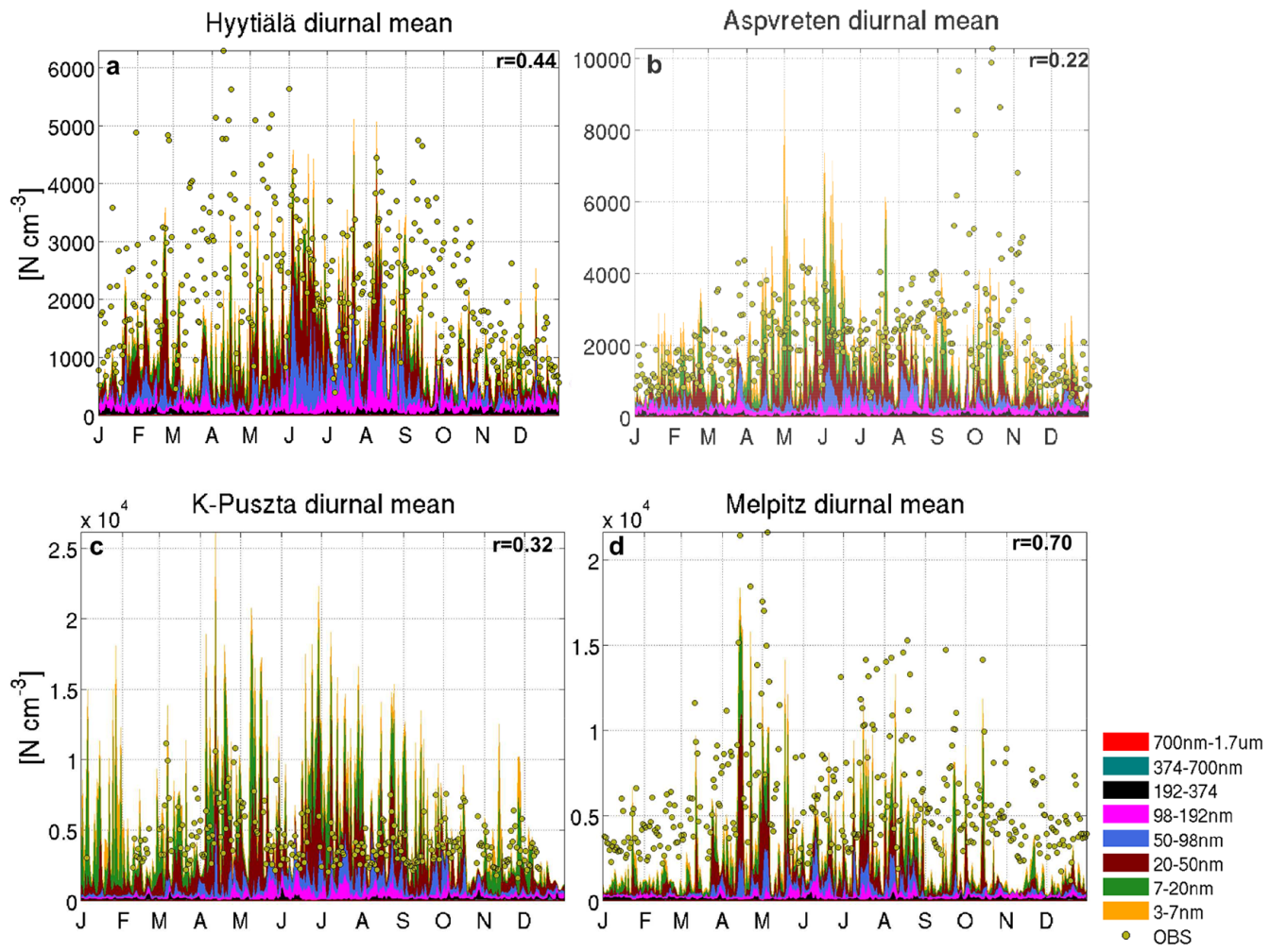

Figure 6. Observed and modeled daily mean particle number concentrations (PNC) at four sites in Europe during 2007 (a-d). Modeled (surfaces) size-resolved and observed total (filled circles) daily mean PNC values are displayed as a time series. See legend for colors representing the different size bins. Observed PNC limit diameters are $3.2 \mathrm{~nm}-1 \mu \mathrm{m}$ for Hyytiälä, $11-418 \mathrm{~nm}$ for Aspvreten, 5.6-1 $\mu \mathrm{m}$ for K-puszta and 3-859 $\mathrm{nm}$ for Melpitz. Units in $\mathrm{cm}^{-3}$.

in the companion paper (Andersson et al., 2015); a lot of the material is also available in Supplement A.

\subsubsection{Size distribution}

The modeled and observed size distributions at all four stations are shown in Fig. 5. A common feature for the PNC size distribution is that PNC values are underestimated, or on the same level as the measurements, except at K-puszta, where the PNC values of the smallest particles are overestimated both during winter and summer (Fig. 5c). At K-puszta, the mean total PNC is overestimated but the PNC in the accumulation mode is underestimated (Fig. 4). At all stations, the shape of the size distribution is captured relatively well, but during winter at K-puszta (Fig. 5c) and during summer at Aspvreten (Fig. 5a) and Hyytiälä (Fig. 5b), the modeled size distribution peaks at smaller sizes than in the observations. The reason for the maximum occurring at too-small sizes, in combination with underestimated accumulation-mode PNC, may be too-weak condensation onto nucleating particles in the model. Bergman et al. (2012) also evaluated the modeled particle number size distribution at measurement sites, including Aspvreten, Melpitz and Hyytiälä, and found that the model ECHAM5-HAM underestimated the number concen- trations at all three measurement sites for sizes larger than about $20 \mathrm{~nm}$, both when using the aerosol dynamics modules of M7 and SALSA. SALSA performed better than M7 for PNC above $100 \mathrm{~nm}$ at the dirtier measurement sites (e.g., Aspvreten and Melpitz) while M7 performed better at cleaner sites (e.g., Hyytiälä), but the differences between the two models were not large. Bergman et al. (2012) concluded that the growth in SALSA probably was too slow.

\subsubsection{Temporal evolution}

Figure 6 shows the modeled and observed temporal variation of the daily mean PNC at the four sites. New particle formation in the model is seen in the form of peak concentrations of the smallest particles sizes. These peaks coincide with the observed maximum total PNC on some occasions; sometimes there is a time shift of a few days between the modeled and observed peaks. Many of the observed nucleation peaks at Hyytiälä (Fig. 6a), Aspvreten (Fig. 6b) and Melpitz (Fig. 6d) are not seen in the model results. Reddington et al. (2011) simulated hourly PNC with diameters larger than $15 \mathrm{~nm}$ using the GLOMAP model and evaluated these against measurements over 1 month (May 2008). Depending on the nucleation parameterization, the correlations $\left(R^{2}\right)$ 


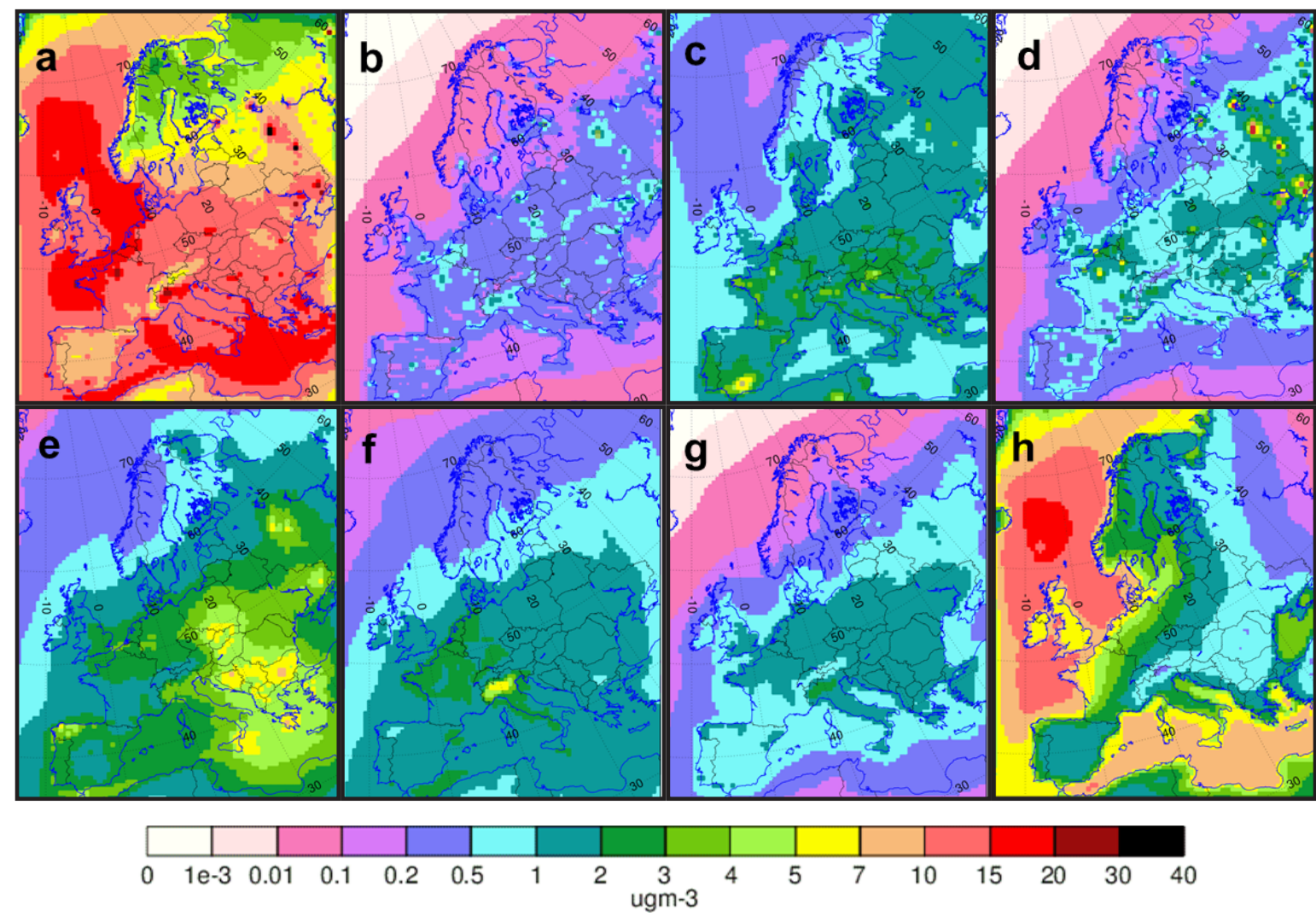

Figure 7. Modeled annual mean concentrations (for 2007) of $\mathrm{PM}_{10}$ (a; peak at $37 \mu \mathrm{g} \mathrm{m}^{-3}$ in Moscow) and its particle components: elemental carbon (b), organic matter (c), anthropogenic primary inorganic aerosol (d), sulfate (e), nitrate (f), ammonium (g) and sea salt (h). Units in $\mu \mathrm{g} \mathrm{m}^{-3}$.

between model and measured PNC were less than 0.03 at Aspvreten, Hyytiälä and Melpitz, and less than 0.10 at Kpuszta. For PNC with larger sizes $(>100 \mathrm{~nm})$, the correlations were less than 0.01 at K-puszta and higher at the other sites $(<0.13$ at Aspvreten, $<0.20$ at Melpitz and $<0.45$ at Hyytiälä). Spracklen et al. (2006), on the other hand, captured the nucleation at Hyytiälä very well with GLOMAP; however, they only studied a short period (22 days) in May with clear sky conditions. With MATCH-SALSA, the hourly correlations $\left(R^{2}\right)$, for single months of 2007, for PNC with a diameter larger than $50 \mathrm{~nm}$ are in the range of $0-0.17$ for Hyytiälä (for May: 0), <0-0.20 for Aspvreten (May: <0), $<0-0.20$ for K-puszta (May: 0.01) and $<0-0.41$ for Melpitz (May: 0.41). These low correlations illustrate that nucleation events are difficult to capture by models when running over long time periods for a large region. One reason for this is the coarse scale of the model - each grid cell is representative of a large area (for MATCH-SALSA, ca. $44 \times 44 \mathrm{~km}^{2}$ and for GLOMAP $2.8^{\circ} \times 2.8^{\circ}$ ). Another reason is that the simple activation-type nucleation scheme needs a site- and time-varying nucleation parameter to work well (Riipinen et al., 2007). Furthermore, the wintertime nucleation peaks in the observations that are absent in the model may also be ex- plained by a temperature dependence in the nucleation that is not accounted for in the model (Dal Maso et al., 2005); or the observed peaks could be of local origin that can not be captured by a regional-scale CTM.

The best correlation between modeled and observed daily mean PNC is found at Melpitz ( $r=0.70$; Fig. 6d) but the model underestimates PNC most of the time; the observed PNC is almost always high at this site. The model grossly overestimates the total PNC at K-puszta (Fig. 6c) during summer, but the temporal variation for particles sizes $>20 \mathrm{~nm}$ follows the measurements fairly well $(r=0.32)$; during winter the model PNC is in better agreement with the observations. At Hyytiälä (Fig. 6a), a lot of nucleation is observed; this is not captured by the model, possibly due to the lack of organic nucleation in this simulation; this will be discussed in detail in the companion paper (Andersson et al., 2015)

Spracklen et al. (2010) calculated the correlations $\left(R^{2}\right)$ between monthly mean modeled and observed PNC for sites where the monthly means varied by more than a factor of 2 during the year 2000 (Aspvreten was excluded due to toosmall of a variation). K-puszta was not included in the assessment. Their results were $R^{2}=0.39$ and 0.28 for the sites 
Hyytiälä and Melpitz, respectively. With MATCH-SALSA, we obtained $R^{2}=0.67$ and 0.08 , respectively, for the same sites (for PNC with diameter $>50 \mathrm{~nm}$ ). Using kinetic nucleation description Spracklen et al. (2010) achieved higher monthly correlations than with activation-type nucleation at most evaluated sites, including Hyytiälä and Melpitz.

\subsection{Model evaluation of particle mass and composition}

Simulated annual average total $\mathrm{PM}_{10}$ and the chemical components that constitute $\mathrm{PM}_{10}$ are displayed in Fig. 7. The largest concentrations of total $\mathrm{PM}_{10}$ (Fig. 7a) are found in anthropogenic emission hotspots (e.g., northern Italy, Moscow and eastern Ukraine) and over the Atlantic Ocean and parts of the Mediterranean Sea. The highest modeled concentrations over land are due to large anthropogenic emissions of primary anthropogenic inorganic aerosol (Fig. 7d), except in northern Italy, where there is a large contribution from ammonium nitrate (Fig. $7 \mathrm{f}-\mathrm{g}$ ), and in southeastern Europe and some sulfur emission hotspots, where sulfate (Fig. 7e) dominates $\mathrm{PM}_{10}$. Over the oceans (and in large parts of western and northern Europe), the largest contribution to $\mathrm{PM}_{10}$ is from sea-salt particles (Fig. 7h); important sulfate contributions are also seen, especially around Mount Etna and the eastern Mediterranean Sea. OM (Fig. 7c) gives the largest modeled non-sea-salt contributions to $\mathrm{PM}_{10}$ in northern Europe and also in some parts of southern and western Europe. In the following subsections we present evaluation statistics for the different particle components.

\subsubsection{Secondary inorganic aerosol (SIA)}

Statistics from the evaluation for SIA components (particulate sulfate, $\mathrm{SO}_{4}^{2-}$; nitrate, $\mathrm{NO}_{3}^{-}$; ammonium, $\mathrm{NH}_{4}^{+}$) are shown in Table 1 and in Supplement A (Tables A15-A19 and Figs. A32-A36). In order to avoid biases due to possible incorrect separation of gas-phase and particle-phase nitrogen in the measurements, we also include evaluation results for total nitrate $\left(\mathrm{TNO}_{3}: \mathrm{HNO}_{3}(\mathrm{~g})+\mathrm{NO}_{3}^{-}(\mathrm{p})\right)$ and total reduced nitrogen $\left(\mathrm{TNH}_{\mathrm{x}}: \mathrm{NH}_{3}(\mathrm{~g})+\mathrm{NH}_{4}^{+}(\mathrm{p})\right)$.

Sulfate has a low mean bias $(4 \%)$ whereas the root mean square error normalized to the observed mean (CV(RMSE)) is around $50 \%$. The average (Pearson) correlation coefficient (average $r$ at the different sites, based on daily means) is 0.52 and the spatial correlation coefficient ("spatial" $r$ for the annual mean concentration at all the stations) is 0.57 . The model performance for the nitrogen compounds $\left(\mathrm{NO}_{3}^{-}\right.$, $\mathrm{HNO}_{3}+\mathrm{NO}_{3}^{-}, \mathrm{NH}_{4}^{+}$and $\mathrm{NH}_{\mathrm{x}}$ ) at individual stations is of similar quality as that for sulfate. The model underestimates the concentration of the nitrogen components by about 10 $20 \%$, while the CV(RMSE) values are a bit lower than for sulfate (ranging from 36 to $49 \%$ for the four $\mathrm{N}$ components). The average $r$ at the measurement sites vary between 0.44 and 0.59 for the $\mathrm{N}$ components, whereas the spatial correlation coefficients are higher (between 0.79 and 0.87 ).

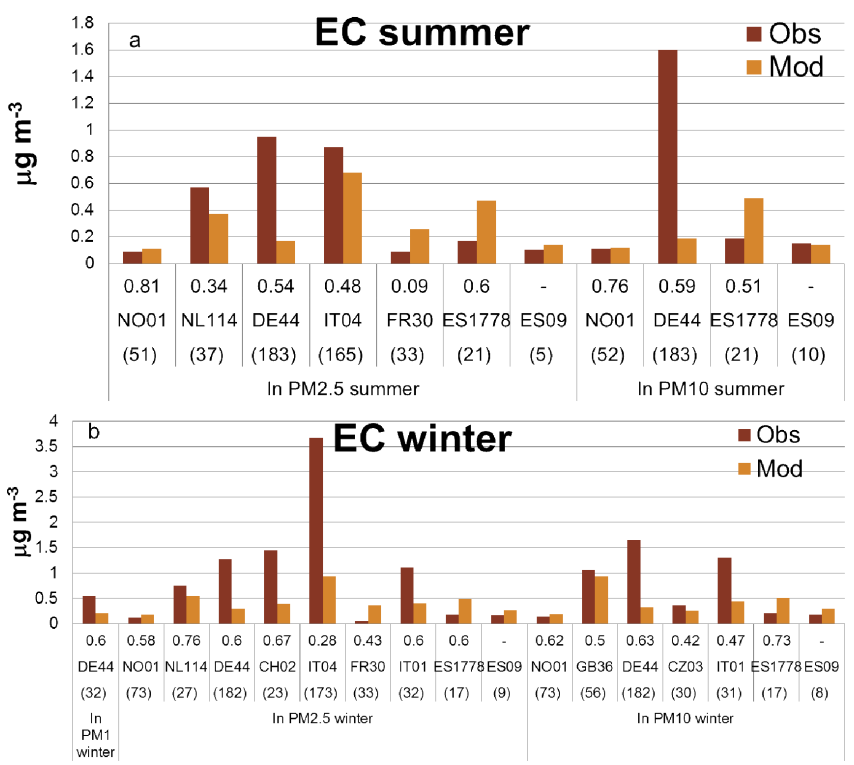

Figure 8. Evaluation of elemental carbon (EC) for 2007 (a: AprilSeptember mean; b: January-March, October-December mean). Observed and modeled mean concentrations $\left(\mu \mathrm{g} \mathrm{m}^{-3}\right)$, and correlation coefficients of daily mean concentrations are indicated below the bars. The number of daily mean values is indicated by the numbers in the parentheses. Correlation coefficients were calculated for measurement sites with more than 10 daily observations. Site codes as defined by EMEP, see Supplement A, Table 5.

\subsubsection{Elemental and organic carbon}

The organic aerosol measurements used for model evaluation in this study are organic carbon (OC) measurements. The model describes organic matter (OM). In the evaluation we assume an OM: OC ratio of 1.4. The actual ratio varies with location and season (e.g., Simon et al., 2011) and is usually between 1.25 and 2.5, with a greater ratio for more aged $\mathrm{OM}$ (Turpin et al., 2000; Kupiainen and Klimont, 2007; Aiken et al., 2008). The choice of a fixed OM: OC ratio for the evaluation will lead to model under- or overestimation, depending on the measurement site and time of year. Figures 8 and 9 show the annual observed and modeled mean concentrations of EC (Fig. 8a-b) and OC (Fig. 9a-b) at individual measurement sites, as well as the associated correlation coefficients, based on daily data; detailed results are given in Table 2 .

Both EC and OC are underestimated at many of the sites. The underestimation is especially large at the Italian sites and Payerne (Switzerland) during winter, for both EC (Fig. 8b) and OC (Fig. 9b), and for EC at Melpitz (Fig. 8a-b). Correlation coefficients are higher for $\mathrm{EC}$ than $\mathrm{OC}$; $\mathrm{OC}$ is more complicated to model than EC, since it is a combination of primary and secondary components, many of them semivolatile. The reasons for the model-measurement differences are likely to vary between seasons and locations; e.g., wintertime emissions from residential combustion are often underestimated (e.g., Simpson et al., 2007; Gilardoni et al., 2011; 
Table 1. Comparison of modeled secondary inorganic aerosol (SIA) components to daily observed concentrations. Average results covering available measurements for the year 2007 (results for individual stations are given in Tables A15-A19 in Supplement A). In addition to the SIA components, the total nitrate $\left(\mathrm{TNO}_{3}=\mathrm{HNO}_{3}(\mathrm{~g})+\mathrm{NO}_{3}^{-}(\mathrm{p})\right)$ and total reduced nitrogen $\left(\mathrm{TNH}_{\mathrm{x}}=\mathrm{NH}_{3}(\mathrm{~g})+\mathrm{NH}_{4}^{+}(\mathrm{p})\right)$ are also evaluated. $r$ : the Pearson correlation coefficient, CV(RMSE): the coefficient of variation of the root mean square error (RMSE normalized to the observed mean concentrations), No. obs: the total number of observations included in the evaluation, No. stns: the number of measurement stations included in the evaluation.

\begin{tabular}{|c|c|c|c|c|c|c|c|c|c|c|}
\hline \multirow[b]{2}{*}{$\begin{array}{l}\text { Measure: } \\
\text { Unit: }\end{array}$} & \multicolumn{6}{|c|}{ Global/temporal } & \multicolumn{4}{|c|}{ Spatial } \\
\hline & $\begin{array}{l}\text { Mean obsvd } \\
\mu \mathrm{gS} / \mathrm{N} \mathrm{m}^{-3}\end{array}$ & $\begin{array}{r}\text { Mean model } \\
\mu \mathrm{gS} / \mathrm{N} \mathrm{m}^{-3}\end{array}$ & $\begin{array}{r}\text { Rel. bias } \\
(\%)\end{array}$ & mean* $r$ & $\begin{array}{r}\text { mean* CV(RMSE) } \\
(\%)\end{array}$ & No. obs & $\begin{array}{r}\text { Rel. bias } \\
(\%)\end{array}$ & $r$ & $\begin{array}{r}\mathrm{CV}(\mathrm{RMSE}) \\
(\%)\end{array}$ & No. stns \\
\hline $\mathrm{SO}_{4}^{2-}$ & 0.63 & 0.65 & 4 & 0.52 & 46 & 16033 & -6 & 0.57 & 53 & 52 \\
\hline $\mathrm{NO}_{3}^{-}$ & 0.40 & 0.32 & -21 & 0.44 & 49 & 7249 & -22 & 0.83 & 48 & 23 \\
\hline $\mathrm{TNO}_{3}$ & 0.49 & 0.40 & -19 & 0.59 & 36 & 11039 & -21 & 0.85 & 41 & 35 \\
\hline $\mathrm{NH}_{4}^{+}$ & 0.72 & 0.64 & -12 & 0.57 & 39 & 9728 & -11 & 0.79 & 37 & 31 \\
\hline $\mathrm{TNH}_{\mathrm{X}}$ & 1.27 & 1.01 & -21 & 0.53 & 40 & 10137 & -20 & 0.87 & 38 & 32 \\
\hline
\end{tabular}

* Weighted average of correlation coefficients and CV(RMSE) values at individual stations.

Table 2. Statistics of the comparison of MATCH-SALSA results to daily observed concentrations of elemental carbon (EC) and organic carbon (OC) in $\mathrm{PM}_{1}, \mathrm{PM}_{2.5}$ and $\mathrm{PM}_{10}$ for the year 2007. Obs stands for measured concentration, Mod for modeled concentration, MAE for mean absolute error, $r=$ Pearson correlation coefficient (only calculated for sites with more than 10 measurements). Relative bias and MAE are given as percentage of the observed average. For further information about the measurement stations, see Table A5 in Supplement A.

\begin{tabular}{|c|c|c|c|c|c|c|c|c|c|c|c|c|c|c|c|}
\hline & \multirow[b]{2}{*}{ Stations } & \multicolumn{7}{|c|}{$\mathrm{EC}$} & \multicolumn{7}{|c|}{$\mathrm{OC}$} \\
\hline & & $\begin{array}{r}\text { Obs } \\
\mu \mathrm{g} \mathrm{m}^{-3}\end{array}$ & $\begin{array}{r}\text { Mod } \\
\mu \mathrm{g} \mathrm{m}^{-3}\end{array}$ & $\begin{array}{l}\text { bias } \\
(\%)\end{array}$ & $\begin{array}{r}\text { MAE } \\
\mu \mathrm{g} \mathrm{m}^{-3}\end{array}$ & $\begin{array}{r}\text { MAE } \\
(\%)\end{array}$ & $r$ & \#meas & $\begin{array}{r}\text { Obs } \\
\mu \mathrm{g} \mathrm{m}^{-3}\end{array}$ & $\begin{array}{r}\text { Mod } \\
\mu \mathrm{g} \mathrm{m}^{-3}\end{array}$ & $\begin{array}{l}\text { bias } \\
(\%)\end{array}$ & $\begin{array}{r}\text { MAE } \\
\mu \mathrm{g} \mathrm{m}^{-3}\end{array}$ & $\begin{array}{r}\text { MAE } \\
(\%)\end{array}$ & $r$ & \#meas \\
\hline In $\mathrm{PM}_{1}$ winter & Melpitz & 0.54 & 0.21 & -60 & 0.33 & 60 & 0.60 & 32 & 0.65 & 0.76 & 18 & 0.23 & 36 & 0.83 & 32 \\
\hline \multirow{9}{*}{ In $\mathrm{PM}_{2.5}$ winter } & Birkenes & 0.12 & 0.18 & 47 & 0.11 & 87 & 0.58 & 73 & 0.60 & 0.88 & 46 & 0.46 & 76 & 0.45 & 73 \\
\hline & Overtoom & 0.75 & 0.54 & -27 & 0.27 & 36 & 0.76 & 27 & 2.19 & 1.15 & -48 & 1.25 & 57 & 0.59 & 28 \\
\hline & Melpitz & 1.28 & 0.29 & -77 & 0.99 & 77 & 0.60 & 182 & 1.81 & 1.21 & -33 & 0.95 & 52 & 0.59 & 182 \\
\hline & Payerne & 1.45 & 0.39 & -73 & 1.06 & 73 & 0.67 & 23 & 5.61 & 1.33 & -76 & 4.28 & 76 & 0.52 & 23 \\
\hline & Ispra & 3.67 & 0.93 & -75 & 2.76 & 75 & 0.28 & 173 & 14.1 & 2.04 & -86 & 12.1 & 86 & 0.24 & 173 \\
\hline & Puy de Dôme & 0.05 & 0.36 & 556 & 0.31 & 556 & 0.43 & 33 & 0.99 & 1.35 & 36 & 0.46 & 46 & 0.60 & 21 \\
\hline & Montelibretti & 1.10 & 0.40 & -64 & 0.70 & 64 & 0.60 & 32 & 17.2 & 1.22 & -93 & 16.0 & 93 & 0.53 & 32 \\
\hline & Montseny & 0.17 & 0.49 & 181 & 0.32 & 181 & 0.60 & 17 & 1.64 & 1.74 & 6 & 0.48 & 29 & 0.68 & 17 \\
\hline & Campisábalos & 0.16 & 0.27 & 65 & 0.10 & 65 & - & 9 & 1.73 & 1.01 & -42 & 0.72 & 42 & - & 9 \\
\hline \multirow[t]{7}{*}{ In $\mathrm{PM}_{10}$ winter } & Birkenes & 0.14 & 0.19 & 38 & 0.10 & 75 & 0.62 & 73 & 0.76 & 0.92 & 22 & 0.48 & 63 & 0.43 & 73 \\
\hline & Harwell & 1.06 & 0.93 & -11 & 0.68 & 64 & 0.50 & 56 & 3.23 & 1.67 & -48 & 1.65 & 51 & 0.70 & 56 \\
\hline & Melpitz & 1.65 & 0.32 & -80 & 1.33 & 80 & 0.63 & 182 & 2.77 & 1.40 & -49 & 1.48 & 53 & 0.56 & 182 \\
\hline & Košetice & 0.36 & 0.25 & -30 & 0.13 & 37 & 0.42 & 30 & 1.96 & 0.86 & -56 & 1.13 & 58 & 0.62 & 30 \\
\hline & Montelibretti & 1.30 & 0.44 & -66 & 0.86 & 66 & 0.47 & 31 & 15.5 & 1.29 & -92 & 14.2 & 92 & 0.65 & 31 \\
\hline & Montseny & 0.21 & 0.51 & 143 & 0.30 & 143 & 0.73 & 17 & 1.61 & 2.03 & 26 & 0.57 & 35 & 0.80 & 17 \\
\hline & Campisábalos & 0.17 & 0.29 & 71 & 0.12 & 71 & - & 8 & 1.92 & 1.25 & -35 & 0.69 & 36 & - & 8 \\
\hline \multirow[t]{7}{*}{ In $\mathrm{PM}_{2.5}$ summer } & Birkenes & 0.09 & 0.11 & 27 & 0.03 & 40 & 0.81 & 51 & 0.74 & 0.85 & 14 & 0.31 & 42 & 0.73 & 51 \\
\hline & Overtoom & 0.57 & 0.37 & -36 & 0.24 & 42 & 0.34 & 37 & 1.66 & 1.17 & -29 & 0.62 & 38 & 0.76 & 37 \\
\hline & Melpitz & 0.95 & 0.17 & -82 & 0.78 & 82 & 0.54 & 183 & 1.26 & 1.78 & 41 & 0.83 & 66 & 0.47 & 183 \\
\hline & Ispra & 0.87 & 0.68 & -21 & 0.35 & 40 & 0.48 & 165 & 3.80 & 2.54 & -33 & 1.91 & 50 & 0.34 & 169 \\
\hline & Puy de Dôme & 0.09 & 0.26 & 171 & 0.18 & 192 & 0.09 & 33 & 2.18 & 2.05 & -6 & 1.57 & 72 & -0.08 & 11 \\
\hline & Montseny & 0.17 & 0.47 & 172 & 0.29 & 172 & 0.60 & 21 & 1.82 & 2.72 & 49 & 0.91 & 50 & 0.60 & 21 \\
\hline & Campisábalos & 0.10 & 0.14 & 46 & 0.05 & 53 & - & 5 & 2.24 & 1.33 & -41 & 1.28 & 57 & - & 5 \\
\hline \multirow[t]{4}{*}{ In $\mathrm{PM}_{10}$ summer } & Birkenes & 0.11 & 0.12 & 10 & 0.04 & 37 & 0.76 & 52 & 1.04 & 0.90 & -13 & 0.27 & 26 & 0.81 & 52 \\
\hline & Melpitz & 1.60 & 0.19 & -88 & 1.41 & 88 & 0.59 & 183 & 2.58 & 1.93 & -25 & 0.87 & 34 & 0.51 & 183 \\
\hline & Montseny & 0.19 & 0.49 & 162 & 0.30 & 162 & 0.51 & 21 & 1.66 & 2.89 & 74 & 1.23 & 74 & 0.62 & 21 \\
\hline & Campisábalos & 0.15 & 0.14 & -9 & 0.08 & 52 & - & 10 & 2.26 & 1.48 & -35 & 1.13 & 50 & - & 9 \\
\hline
\end{tabular}

Bergström et al., 2012), and during the summer half-year biogenic VOC emissions and wildfires may be more important sources of carbonaceous particles.

At Ispra (IT04) in northern Italy, the model performs fairly well for carbonaceous aerosol during summer but greatly underestimates both EC and OC during wintertime (Figs. 8, 9 and Fig. A15 in Supplement A). One reason may be the underestimation of residential wood combustion emissions (e.g., Bergström et al., 2012). The model also underestimates $\mathrm{NO}_{2}$ (by $43 \%$ in summer and $51 \%$ in winter). Both the observations and the model results show a clear seasonal cycle with higher concentrations during winter for $\mathrm{NO}_{2}$ as well as for EC and OC. However, for EC and OC the model underestimation during winter is much larger $(-74$ and $-87 \%$, 

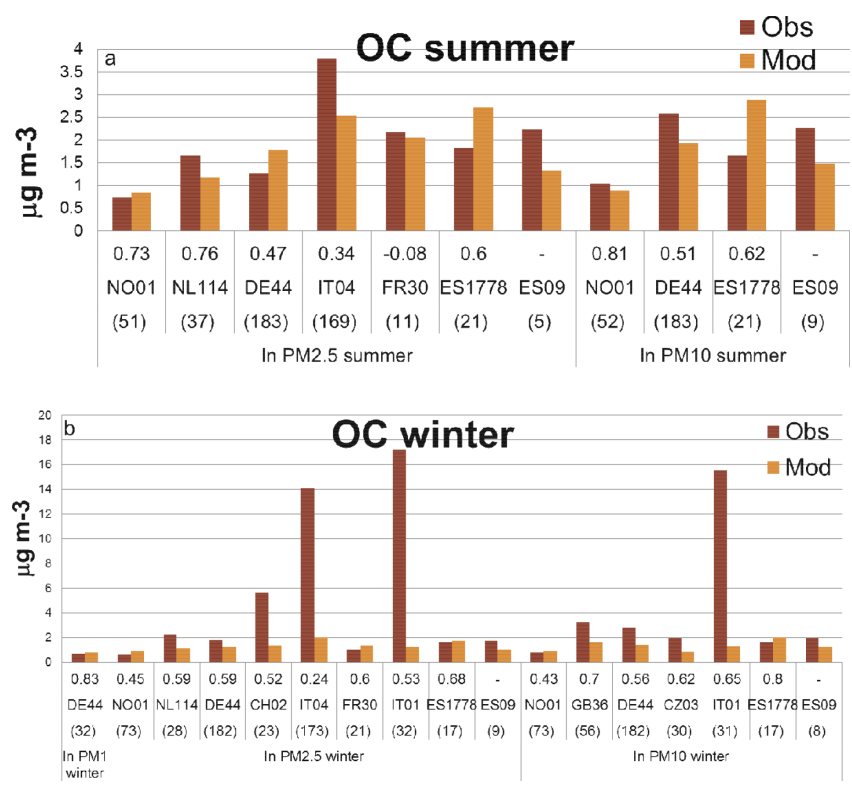

Figure 9. As Fig. 8 but for organic carbon (OC).

respectively) than during summer $(-20$ and $-37 \%$, respectively) (Supplement A, Fig. A15). The poor model performance for $\mathrm{EC}$ and $\mathrm{OC}$ during winter is likely due to a lack of emissions from one or more emission sectors, with greater emissions of EC and OC during winter, but relatively small contribution to $\mathrm{NO}_{2}$. This work therefore supports the results of previous studies (e.g., Gilardoni et al., 2011) that have concluded that residential wood combustion emissions are likely underestimated in current emission inventories, at least in the area around Ispra.

For the German site Melpitz, the model grossly underestimates EC throughout the year (Supplement A, Fig. A37). OC is generally captured fairly well at the station, with underestimation of $\mathrm{OC}$ in $\mathrm{PM}_{2.5}$ and $\mathrm{PM}_{10}$ (but not $\mathrm{PM}_{1}$ ) during winter and overestimation for $\mathrm{OC}$ in $\mathrm{PM}_{2.5}$ and underestimation $(-25 \%)$ in $\mathrm{PM}_{10}$ during summer (Supplement A, Fig. A38). Part of the reason for the relatively high EC measurements at Melpitz is that the measurement technique used at this site to separate OC from EC has no charring correction and is expected to lead to too-high EC values and to underestimate OC (see Genberg et al., 2013, and references therein). There are large peaks during spring and late autumn of OC (and EC) in $\mathrm{PM}_{2.5}$ and $\mathrm{PM}_{10}$, which are clearly underpredicted. The peak in the beginning of April coincides with a vegetation fire episode (Genberg et al., 2013); the earlier peaks and the late autumn peaks are perhaps more likely due to residential combustion or other missing/underestimated sources, possibly, also due to fires in eastern Europe (Jönsson et al., 2013). Stern et al. (2008) compared five different chemical transport models to observations from northern and eastern Germany during highly polluted conditions. None of the models could reproduce the very high EC concentrations observed at Mel-

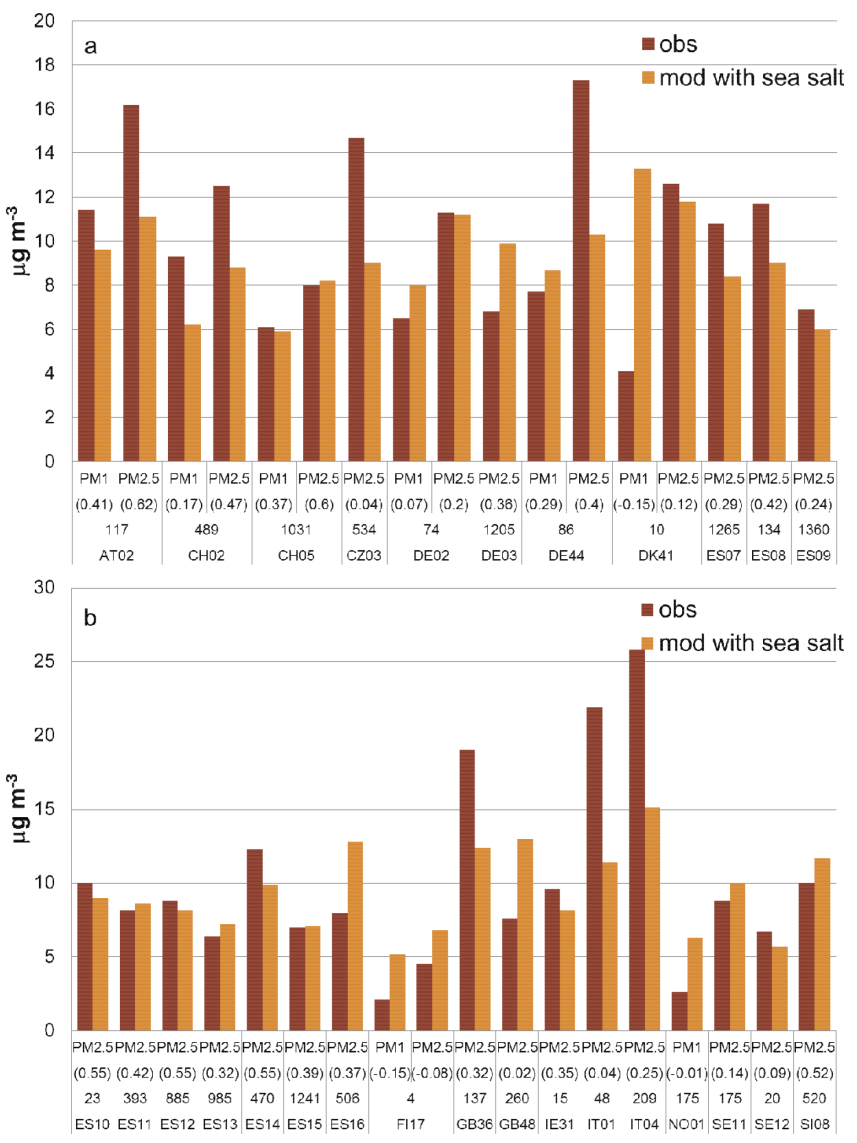

Figure 10. Evaluation of $\mathrm{PM}_{1}$ and $\mathrm{PM}_{2.5}$ for 2007. Observed and modeled mean concentrations $\left(\mu \mathrm{g} \mathrm{m}^{-3}\right)$; correlation coefficients of daily mean concentrations are indicated below the bars within parentheses. The elevation of each site is included below the correlation coefficients (units in meters above sea level). Station codes as defined by EMEP, see Supplement A, Table 5.

pitz. Stern et al. (2008) suggested that the large underestimations of EC may be an indication that emissions in the central European region were underestimated during these episodes.

\subsubsection{Total particulate matter $\left(\mathbf{P M}_{1}\right.$ and $\left.\mathbf{P M}_{2.5}\right)$}

Evaluation of $\mathrm{PM}_{1}$ and $\mathrm{PM}_{2.5}$ at 28 measurement sites is presented in Fig. 10 and in Supplement A (Table A21 and Fig. A39); detailed time series plots are given in Supplement A, Figs. A17, A40-A41. For $\mathrm{PM}_{1}$ the annual means at the sites with the lowest observed concentration (three Nordic sites: NO01, FI17, DK41) are overestimated by the model. On the other hand, at the central European sites the $\mathrm{PM}_{1}$ concentrations are much better captured. The model underestimates $\mathrm{PM}_{2.5}$ by $14 \%$ (spatial average) and the spatial correlation coefficient is 0.64 . Six of the 35 evaluated annual means $\left(\mathrm{PM}_{1}\right.$ and $\left.\mathrm{PM}_{2.5}\right)$ deviate by more than $50 \%$ from the measured concentrations. The largest underestimations of $\mathrm{PM}_{2.5}$ are seen at the sites with the highest observed annual mean. The underestimation of $\mathrm{PM}_{2.5}$ can be due to a 
number of reasons, including underestimated emissions, tooshort aerosol lifetime or too-small secondary aerosol production. There is probably too little EC and OC in the model, at least at some of the sites, which can be explained by underestimated emissions.

The treatment of sea spray needs to be further evaluated and the model scheme for sea-salt particles may need to be updated. For $\mathrm{PM}_{1}$ the annual means at the sites with the lowest concentrations are overestimated by the model. This seems to be partly due to overestimation of sea salt. Evaluation scores for modeled $\mathrm{PM}_{1}$ and $\mathrm{PM}_{2.5}$ excluding sea-salt aerosol in the total PM mass (see Supplement A, Table A21, Figs. A18 and A39) give higher correlation coefficients for daily mean $\mathrm{PM}_{2.5}$ or $\mathrm{PM}_{1}$ at 22 of the 28 sites (and lower at only one site) than when sea salt is included. This is an indication of too much sea salt at the wrong time. It may be due to too-strong sea-salt emissions and/or too-weak sink processes for the sea salt, since substantial improvements in correlation are seen also at some far inland sites.

\section{Conclusions}

We have implemented the sectional aerosol dynamics model SALSA (Kokkola et al., 2008) in the European-scale CTM MATCH (Multi-scale Atmospheric Transport and Chemistry; Robertson et al., 1999). The new model is called MATCH-SALSA. It includes aerosol microphysics with several options for nucleation, wet scavenging and condensation.

In general, the model reproduces the observed lower particle number concentration (PNC) in northern and northwestern Europe and remote regions than in central Europe. The model peak in the particle number size distribution occurs at the same or smaller particle size as the observed peak. Total PNC is underestimated at northern and central European sites. The low nucleation rate coefficient used in this study is probably one important factor for the underestimation, although other reasons may also contribute; e.g., organic nucleation is not included and EC is not emitted in the Aitken mode. The model performs well for particle mass, including secondary inorganic aerosol components. Particulate elemental and organic carbon concentrations are underestimated at many of the sites.

Before using the model for simulating total $\mathrm{PM}_{2.5}$, the SOA formulation needs further improvements. MATCHSALSA is computationally costlier than MATCH, which also puts restrictions on when the model can be used.

The development of the MATCH-SALSA model is continuing and in the near future focus will be on the following areas:

- An updated biogenic emission module is needed for realistic treatment of BSOA formation. Updating the biogenic SOA scheme will likely have a large impact on modeled $\mathrm{PM}_{2.5}$ and also affect the model performance for total PNC through impacts on nucleation and condensation.

- Updating the nucleation rate coefficients possibly with time- and space-varying rate coefficients.

- Nitrogen gas-particle partitioning should be coupled to the microphysics. This may increase condensational growth, which is underestimated in the present version of the model.

- Emissions from open fires (wildfires and agricultural burning activities) will be added to the model.

- Dust emissions from road traffic, agricultural activities and non-vegetated soils including desert areas should be included in the model.

- Processes affecting sea salt need further work and evaluation. This study has shown large modeled sea-salt peaks that are not seen in the measurements. Both emissions and deposition of sea-salt particles should be investigated.

- Emission inventories need to be improved, especially for EC and OC emissions.

\section{The Supplement related to this article is available online at doi:10.5194/gmd-8-171-2015-supplement.}

Acknowledgements. This work was financed by the Swedish Environmental Protection Agency (Naturvårdsverket) through the Swedish Clean Air Research Programme (SCARP; http://www.scarp.se) and the Swedish Clean Air and Climate research programme (SCAC; http://www.scac.se). We also acknowledge funding from the Swedish Research Council FORMAS under the MACCII project (no. 2009-409) and from the Academy of Finland (decision: 250348).

Edited by: G. Mann

\section{References}

Aan de Brugh, J. Schaap, M., Vignati, E., Dentener, F., Kahnert, M., Sofiev, M., Huijnen, V., and Krol, M. C.: The European aerosol budget in 2006, Atmos. Chem. Phys., 11, 1117-1139, doi:10.5194/acp-11-1117-2011, 2011.

Abdul-Razzak, H. and Ghan, S. J.: A parameterization of aerosol activation, 3. Sectional representation, J. Geophys. Res., 107, 4026, doi:10.1029/2001JD000483, 2002..

Adams, P. J. and Seinfeld, J. H.: Predicting global aerosol size distributions in general circulation models, J. Geophys. Res. D, 107, AAC 4-1-AAC 4-3, 2002.

Ahlm, L., Julin, J., Fountoukis, C., Pandis, S. N., and Riipinen, I.: Particle number concentrations over Europe in 2030: the role of emissions and new particle formation, Atmos. Chem. Phys., 13, 10271-10283, doi:10.5194/acp-13-10271-2013, 2013. 
Aiken, A. C., Decarlo, P. F., Kroll, J. H., Worsnop, D. R., Huffman, J. A., Docherty, K. S., Ulbrich, I. M., Mohr, C., Kimmel, J. R., Sueper, D., Sun, Y., Zhang, Q., Trimborn, A., Northway, M., Ziemann, P. J., Canagaratna, M. R., Onasch, T. B., Alfarra, M. R., Prevot, A. S. H., Dommen, J., Duplissy, J., Metzger, A., Baltensperger, U., and Jimenez, J. L.: O/C and OM/OC ratios of primary, secondary, and ambient organic aerosols with highresolution time-of-flight aerosol mass spectrometry, Environ. Sci. Technol., 42, 4478-4485, doi:10.1021/es703009q, 2008.

Andersson, C., Langner, J., and Bergström, R.: Interannual variation and trends in air pollution over Europe due to climate variability during 1958-2001 simulated with a regional CTM coupled to the ERA40 reanalysis, Tellus, 59B, 77-98, 2007.

Andersson, C., Bergström, R., and Johansson, C.: Population exposure and mortality due to regional background PM in Europe - long-term simulations of source region and shipping contributions, Atmos. Environ., 43, 3614-3620, 2009.

Andersson, C., Bergström, R., Bennet, C, Thomas, M., Robertson, L., Kokkola, H., Korhonen, H., and Lehtinen, K.: MATCH-SALSA - Multi-scale Atmospheric Transport and Chemistry model coupled to the SALSA aerosol microphysics model, SMHI RMK Report no 115, available at: http://www.smhi.se/publikationer/match-salsa-multi-scaleatmospheric-transport-and-chemistry-model-coupled-tothe-salsa-aerosol-microphysics-model-1.34623 (last access: 2 February 2015), 2013.

Andersson, C. et al.: MATCH-SALSA - Multi-scale Atmospheric Transport and Chemistry model coupled to the SALSA aerosol microphysics model - Part 2: Sensitivity tests, Geosci. Model Dev. Discuss., in preparation, 2015.

Atkinson, R., Baulch, D. L., Cox, R. A., Crowley, J. N., Hampson, R. F., Hynes, R. G., Jenkin, M. E., Rossi, M. J., Troe, J., and IUPAC Subcommittee: Evaluated kinetic and photochemical data for atmospheric chemistry: Volume II - gas phase reactions of organic species, Atmos. Chem. Phys., 6, 3625-4055, doi:10.5194/acp-6-3625-2006, 2006.

Bauer, S. E., Wright, D. L., Koch, D., Lewis, E. R., McGraw, R., Chang, L.-S., Schwartz, S. E., and Ruedy, R.: MATRIX (Multiconfiguration Aerosol TRacker of mIXing state): an aerosol microphysical module for global atmospheric models, Atmos. Chem. Phys., 8, 6003-6035, doi:10.5194/acp-8-60032008, 2008.

Berge, E.: Coupling of wet scavenging of sulphur to clouds in a numerical weather prediction model, Tellus, 45B, 1-22, 1992.

Bergström, R., Denier van der Gon, H. A. C., Prévôt, A. S. H., Yttri, K. E., and Simpson, D.: Modelling of organic aerosols over Europe (2002-2007) using a volatility basis set (VBS) framework: application of different assumptions regarding the formation of secondary organic aerosol, Atmos. Chem. Phys., 12, 8499-8527, doi:10.5194/acp-12-8499-2012, 2012.

Bergman, T., Kerminen, V.-M., Korhonen, H., Lehtinen, K. J., Makkonen, R., Arola, A., Mielonen, T., Romakkaniemi, S., Kulmala, M., and Kokkola, H.: Evaluation of the sectional aerosol microphysics module SALSA implementation in ECHAM5HAM aerosol-climate model, Geosci. Model Dev., 5, 845-868, doi:10.5194/gmd-5-845-2012, 2012.

Bergström, R., Hallquist, M., Simpson, D., Wildt, J., and Mentel, T. F.: Biotic stress: a significant contributor to organic aerosol in Eu- rope?, Atmos. Chem. Phys., 14, 13643-13660, doi:10.5194/acp14-13643-2014, 2014.

Binkowski, F. S. and Shankar, U.: The regional Particulate Matter model: 1. Model description and preliminary results, J. Geophys. Res., 100, 26191-26209, 1995.

Byun, D. and Schere, K. L.: Review of the governing equations, computational algorithms, and other components of the models3 community multiscale air quality (CMAQ) modeling system, Appl. Mech. Rev., 59, 51-77, 2006.

Carter, W. P. L.: Condensed atmospheric photooxidation mechanism for isoprene, Atmos. Environ., 30, 4275-4290, 1996.

Chamberlain, A. C. and Chadwick, R. C.: Transport of iodine from atmosphere to ground, Tellus, 18, 226-237, 1965.

Chen, Y. and Penner, J. E.: Uncertainty analysis for estimates of the first indirect aerosol effect, Atmos. Chem. Phys., 5, 2935-2948, doi:10.5194/acp-5-2935-2005, 2005.

Dal Maso, M., Kulmala, M., Riipinen, I., Wagner, R., Hussein, T., Aalto, P. P., and Lehtinen, K. E.: Formation and growth of fresh atmospheric aerosols: eight years of aerosol size distribution data from SMEAR II, Hyytiala, Finland, Boreal Environ. Res., 10, 323-336, 2005.

Dana, M. T. and Hales, J. M.: Statistical aspects of the washout of polydisperse aerosols, Atmos. Environ., 10, 45-50, 1976.

Ehn, M., Thornton, J. A., Kleist, E., Sipilä, M., Junninen, H., Pullinen, I., Springer, M., Rubach, F., Tillmann, R., Lee, B., LopezHilfiker, F., Andres, S., Acir, I.-H., Rissanen, M., Jokinen, T., Schobesberger, S., Kangasluoma, J., Kontkanen, J., Nieminen, T., Kurtén, T., Nielsen, L. B., Jørgensen, S., Kjaergaard, H. G., Canagaratna, M., Dal Maso, M., Berndt, T., Petäjä, T., Wahner, A., Kerminen, V.-M., Kulmala, M., Worsnop, D. R., and Mentel, T. F.: A large source of low-volatility secondary organic aerosol, Nature, 506, 476-479, doi:10.1038/nature13032, 2014.

Foltescu, V. L., Pryor, C. S., and Bennet, C.: Sea salt generation, dispersion and removal on the regional scale, Atmos. Environ. 39, 2123-2133, 2005.

Fountoukis, C., Racherla, P. N., Denier van der Gon, H. A. C., Polymeneas, P., Charalampidis, P. E., Pilinis, C., Wiedensohler, A., Dall'Osto, M., O'Dowd, C., and Pandis, S. N.: Evaluation of a three-dimensional chemical transport model (PMCAMx) in the European domain during the EUCAARI May 2008 campaign, Atmos. Chem. Phys., 11, 10331-10347, doi:10.5194/acp11-10331-2011, 2011.

Friedrich, R. and Reis, S. (Eds.): Emissions of air pollutants - measurements, calculations and uncertainties, Springer, ISBN 978-3540-00840-8, 2004.

Frohn, L. M., Christensen, J. H., and Brandt, J.: Development of a high-resolution nested air pollution model - The numerical approach, J. Comput. Phys., 179, 68-94, 2002.

Gelbard, F., Tambour, Y., and Seinfeld, J. H.: Sectional representations for simulating aerosol dynamics, J. Colloid Interf. Sci., 76, 541-556, 1980.

Genberg, J., Denier van der Gon, H. A. C., Simpson, D., Swietlicki, E., Areskoug, H., Beddows, D., Ceburnis, D., Fiebig, M. Hansson, H. C., Harrison, R. M., Jennings, S. G., Saarikoski, S., Spindler, G., Visschedijk, A. J. H., Wiedensohler, A., Yttri, K. E., and Bergström, R.: Light-absorbing carbon in Europe - measurement and modelling, with a focus on residential wood combustion emissions, Atmos. Chem. Phys., 13, 87198738, doi:10.5194/acp-13-8719-2013, 2013. 
Gidhagen, L., Johansson, C., Langner, J., and Foltescu, V.: Urban scale modeling of particle number concentration in Stockholm, Atmos. Environ., 39, 1711-1725, 2005.

Gilardoni, S., Vignati, E., Cavalli, F., Putaud, J. P., Larsen, B. R., Karl, M., Stenström, K., Genberg, J., Henne, S., and Dentener, F.: Better constraints on sources of carbonaceous aerosols using a combined ${ }^{14} \mathrm{C}$ - macro tracer analysis in a European rural background site, Atmos. Chem. Phys., 11, 5685-5700, doi:10.5194/acp-11-5685-2011, 2011.

Heintzenberg, J., Birmili, W., Wiedensohler, A., Nowak, A., and Tuch, T.: Structure, variability and persistence of the submicrometre marine aerosol, Tellus, 56B, 357-367, 2004.

Jacobson, M. Z.: Developing, coupling and applying a gas, aerosol, transport and radiation model to study urban and regional air pollution, Ph.D. thesis, Dept. of Atmospheric Sciences, University of California, Los Angeles, 1994.

Jacobson, M. Z.: Numerical techniques to solve condensational and dissolutional growth equations when growth is coupled to reversible reactions, Aerosol Sci. Technol., 27, 491-498, 1997.

Jacobson, M. Z.: Analysis of aerosol interactions with numerical techniques for solving coagulation, nucleation, condensation, dissolution, and reversible chemistry among multiple size distributions, J. Geophys. Res., 107, 4366, doi:10.1029/2001JD002044, 2002.

Jacobson, M. Z.: Fundamentals of atmospheric modeling. Second edition. Cambridge university press, 2005.

Jenkin, M. E., Saunders, S. M., and Pilling, M. J.: The tropospheric degradation of volatile organic compounds: a protocol for mechanism development, Atmos. Environ., 31, 81-104, 1997.

Jönsson, O., Andersson, C., Forsberg, B., and Johansson, C.: Air pollution episodes in Stockholm regional background air due to sources in Europe and their effects on human population, Boreal Environ. Res., 18, 280-302, 2013.

Kahnert, M.: Variational data analysis of aerosol species in a regional CTM: background error covariance constraint and aerosol optical observation operators, Tellus, 60B: 753-770, 2008.

Kahnert, M.: On the observability of chemical and physical aerosol properties by optical observations: Inverse modelling with variational data assimilation, Tellus, 61B, 747-755, 2009.

Knol, A. B., de Hartog, J. J., Boogaard, H., Slottje, P., van der Sluijs, J. P., Lebret, E., Cassee, F. R., Wardekker, J. A., Ayres, J. G., Borm, P. J., Brunekreef, B., Donaldson, K., Forastiere, F., Holgate, S. T., Kreyling, W. G., Nemery, B., Pekkanen, J., Stone, V., Wichmann, H. E., and Hoek, G.: Expert elicitation on ultrafine particles: likelihood of health effects and causal pathways, Particle Fibre Toxicol., 6, 19, doi:10.1186/1743-8977-6-19, 2009.

Kokkola, H., Korhonen, H., Lehtinen, K. E. J., Makkonen, R., Asmi, A., Järvenoja, S., Anttila, T., Partanen, A.-I., Kulmala, M., Järvinen, H., Laaksonen, A., and Kerminen, V.-M.: SALSA - a Sectional Aerosol module for Large Scale Applications, Atmos. Chem. Phys., 8, 2469-2483, doi:10.5194/acp-8-2469-2008, 2008.

Kokkola, H., Yli-Pirilä, P., Vesterinen, M., Korhonen, H., Keskinen, H., Romakkaniemi, S., Hao, L., Kortelainen, A., Joutsensaari, J., Worsnop, D. R., Virtanen, A., and Lehtinen, K. E. J.: The role of low volatile organics on secondary organic aerosol formation, Atmos. Chem. Phys., 14, 1689-1700, doi:10.5194/acp-14-16892014, 2014
Korhola, T., Kokkola, H., Korhonen, H., Partanen, A.-I., Laaksonen, A., Lehtinen, K. E. J., and Romakkaniemi, S.: Reallocation in modal aerosol models: impacts on predicting aerosol radiative effects, Geosci. Model Dev., 7, 161-174, doi:10.5194/gmd7-161-2014, 2014.

Kuenen, J., Denier van der Gon, H., Visschedijk, A., van der Brugh, H., van Gijlswijk, R.: MACC European emission inventory for the years 2003-2007, TNO report, TNO-060-UT-2011-00588, 2011.

Kukkonen, J., Olsson, T., Schultz, D. M., Baklanov, A., Klein, T., Miranda, A. I., Monteiro, A., Hirtl, M., Tarvainen, V., Boy, M., Peuch, V.-H., Poupkou, A., Kioutsioukis, I., Finardi, S., Sofiev, M., Sokhi, R., Lehtinen, K. E. J., Karatzas, K., San José, R., Astitha, M., Kallos, G., Schaap, M., Reimer, E., Jakobs, H., and Eben, K.: A review of operational, regional-scale, chemical weather forecasting models in Europe, Atmos. Chem. Phys., 12, 1-87, doi:10.5194/acp-12-1-2012, 2012.

Kulmala, M., Lehtinen, K. E. J., and Laaksonen, A.: Cluster activation theory as an explanation of the linear dependence between formation rate of $3 \mathrm{~nm}$ particles and sulphuric acid concentration, Atmos. Chem. Phys., 6, 787-793, doi:10.5194/acp-6-787-2006, 2006.

Kupiainen, K. and Klimont, Z.: Primary emissions of fine carbonaceous particles in Europe, Atmos. Environ., 41, 2156-2170, 2007.

Langner, J., Bergström, R., and Pleijel, H.: European scale modeling of sulfur, oxidised nitrogen and photochemical oxidants. Model development and evaluation for the 1994 growing season, SMHI RMK 82, SMHI SE-60176 Norrköping, Sweden, 1998.

Lee, L. A., Pringle, K. J., Reddington, C. L., Mann, G. W., Stier, P., Spracklen, D. V., Pierce, J. R., and Carslaw, K. S.: The magnitude and causes of uncertainty in global model simulations of cloud condensation nuclei, Atmos. Chem. Phys., 13, 8879-8914, doi:10.5194/acp-13-8879-2013, 2013.

Lee, Y. H. and Adams, P. J.: Evaluation of aerosol distributions in the GISS-TOMAS global aerosol microphysics model with remote sensing observations, Atmos. Chem. Phys., 10, 2129-2144, doi:10.5194/acp-10-2129-2010, 2010.

Lehtinen, K. E. J., Dal Maso, M., Kulmala, M., and Kerminen, V.-M. Estimating nucleation rates from apparent particle formation rates and vice versa: revised formulation of the Kerminen-Kulmala equation, Aerosol Sci., 38, 998-994, doi:10.1016/j.jaerosci.2007.06.009, 2007.

Liu, X., Easter, R. C., Ghan, S. J., Zaveri, R., Rasch, P., Shi, X., Lamarque, J.-F., Gettelman, A., Morrison, H., Vitt, F., Conley, A., Park, S., Neale, R., Hannay, C., Ekman, A. M. L., Hess, P., Mahowald, N., Collins, W., Iacono, M. J., Bretherton, C. S., Flanner, M. G., and Mitchell, D.: Toward a minimal representation of aerosols in climate models: description and evaluation in the Community Atmosphere Model CAM5, Geosci. Model Dev., 5, 709-739, doi:10.5194/gmd-5-709-2012, 2012.

Lohmann, U. and Feichter, J.: Global indirect aerosol effects: a review, Atmos. Chem. Phys., 5, 715-737, doi:10.5194/acp-5-7152005, 2005.

Mann, G. W., Carslaw, K. S., Ridley, D. A., Spracklen, D. V., Pringle, K. J., Merikanto, J., Korhonen, H., Schwarz, J. P., Lee, L. A., Manktelow, P. T., Woodhouse, M. T., Schmidt, A., Breider, T. J., Emmerson, K. M., Reddington, C. L., Chipperfield, M. P., and Pickering, S. J.: Intercomparison of modal and sectional 
aerosol microphysics representations within the same 3-D global chemical transport model, Atmos. Chem. Phys., 12, 4449-4476, doi:10.5194/acp-12-4449-2012, 2012.

Mann, G. W., Carslaw, K. S., Reddington, C. L., Pringle, K. J., Schulz, M., Asmi, A., Spracklen, D. V., Ridley, D. A., Woodhouse, M. T., Lee, L. A., Zhang, K., Ghan, S. J., Easter, R. C., Liu, X., Stier, P., Lee, Y. H., Adams, P. J., Tost, H., Lelieveld, J., Bauer, S. E., Tsigaridis, K., van Noije, T. P. C., Strunk, A., Vignati, E., Bellouin, N., Dalvi, M., Johnson, C. E., Bergman, T., Kokkola, H., von Salzen, K., Yu, F., Luo, G., Petzold, A., Heintzenberg, J., Clarke, A., Ogren, J. A., Gras, J., Baltensperger, U., Kaminski, U., Jennings, S. G., O'Dowd, C. D., Harrison, R. M., Beddows, D. C. S., Kulmala, M., Viisanen, Y., Ulevicius, V., Mihalopoulos, N., Zdimal, V., Fiebig, M., Hansson, H.-C., Swietlicki, E., and Henzing, J. S.: Intercomparison and evaluation of global aerosol microphysical properties among AeroCom models of a range of complexity, Atmos. Chem. Phys., 14, 4679-4713, doi:10.5194/acp-14-4679-2014, 2014.

Mentel, Th. F., Wildt, J., Kiendler-Scharr, A., Kleist, E., Tillmann, R., Dal Maso, M., Fisseha, R., Hohaus, Th., Spahn, H., Uerlings, R., Wegener, R., Griffiths, P. T., Dinar, E., Rudich, Y., and Wahner, A.: Photochemical production of aerosols from real plant emissions, Atmos. Chem. Phys., 9, 4387-4406, doi:10.5194/acp9-4387-2009, 2009.

Metzger, A., Verheggen, B., Dommen, J., Duplissy, J., Prevot, A. S. H., Weingartner, E., Riipinen, I., Kulmala, M., Spracklen, D. V., Carslaw, K. S., and Baltensperger, U.: Evidence for the role of organics in aerosol particle formation under atmospheric conditions, P. Natl. Acad. Sci. USA, 107, 6646-6651, 2010.

Monahan, E. C., Spiel, D. E., and Davidson, K. L.: A model of marine aerosol generation via whitecaps and wave disruption, in: Oceanic Whitecaps and Their Role in Air-Sea Exchange, edited by: Monahan, E. C. and Mac Niocaill, G., D Reidel, Norwell, MA, 167-174, 1986.

Morgan, W. T., Allan, J. D., Bower, K. N., Esselborn, M., Harris, B., Henzing, J. S., Highwood, E. J., Kiendler-Scharr, A., McMeeking, G. R., Mensah, A. A., Northway, M. J., Osborne, S., Williams, P. I., Krejci, R., and Coe, H.: Enhancement of the aerosol direct radiative effect by semi-volatile aerosol components: airborne measurements in North-Western Europe, Atmos. Chem. Phys., 10, 8151-8171, doi:10.5194/acp-10-81512010, 2010.

Mårtensson, E. M., Nilsson, E. D., de Leeuw, G., Cohen, L. H., and Hansson, H.-C.: Laboratory simulations and parametrization of the primary marine aerosol production. J. Geophys. Res., 108, 4297, doi:10.1029/2002JD002263, 2003.

Napari, I., Noppel, M., Vehkamäki, H., and Kulmala, M..: An improved model for ternary nucleation of sulfuric acid-ammoniawater, J. Chem. Phys., 116, 4221-4227, 2002a.

Napari, I., Noppel, M., Vehkamäki, H., and Kulmala, M.: Parameterization of ternary nucleation rates for $\mathrm{H}_{2} \mathrm{SO}_{4}-\mathrm{NH}_{3}-\mathrm{H}_{2} \mathrm{O}$ vapors, J. Geophys. Res., 107, AAC 6-1, 2002b.

Oberdörster, G., Gelein, R., Ferin, J., and Weiss, B.: Association of particulate air pollution and acute mortality: involvement of ultrafine particles, Inhalation Toxicol., 71, 111-124, 1995.

O’Dowd, C. D., Facchini, M. C., Cavalli, F., Ceburnis, D., Mircea, M., Decesari, S., Fuzzi, S., Yoon, Y. J., and Putaud, J.-P.: Biogenically driven organic contribution to marine aerosol, Nature, 431, 676-680, 2004.
Paasonen, P., Nieminen, T., Asmi, E., Manninen, H. E., Petäjä, T., Plass-Dülmer, C., Flentje, H., Birmili, W., Wiedensohler, A., Hõrrak, U., Metzger, A., Hamed, A., Laaksonen, A., Facchini, M. C., Kerminen, V.-M., and Kulmala, M.: On the roles of sulphuric acid and low-volatility organic vapours in the initial steps of atmospheric new particle formation, Atmos. Chem. Phys., 10, 11223-11242, doi:10.5194/acp-10-11223-2010, 2010.

Peters, A., Wichmann, E., Tuch, T., Heinrich, J., and Heyder, J.: Respiratory effects are associated with the number of fine particles, Am. J. Respir. Crit. Care Med., 155, 1376-1383, 1997.

Pope, C. A. and Dockery, D. W.: Health effects of fine particulate air pollution: lines that connect, J. Air Waste Manage. Assoc., 56, 709-741, 2006.

Pouliot, G., Thomas Pierce, T., Denier van der Gon, H., Schaap, M., Moran, M., and Nopmongcol, U.: Comparing emission inventories and model-ready emission datasets between Europe and North America for the AQMEII project, Atmos. Environ., 53, 4 14, 2012.

Pringle, K. J., Tost, H., Message, S., Steil, B., Giannadaki, D., Nenes, A., Fountoukis, C., Stier, P., Vignati, E., and Lelieveld, J.: Description and evaluation of GMXe: a new aerosol submodel for global simulations (v1), Geosci. Model Dev., 3, 391-412, doi:10.5194/gmd-3-391-2010, 2010.

Reddington, C. L., Carslaw, K. S., Spracklen, D. V., Frontoso, M. G., Collins, L., Merikanto, J., Minikin, A., Hamburger, T., Coe, H., Kulmala, M., Aalto, P., Flentje, H., Plass-Dülmer, C., Birmili, W., Wiedensohler, A., Wehner, B., Tuch, T., Sonntag, A., O’Dowd, C. D., Jennings, S. G., Dupuy, R., Baltensperger, U., Weingartner, E., Hansson, H.-C., Tunved, P., Laj, P., Sellegri, K., Boulon, J., Putaud, J.-P., Gruening, C., Swietlicki, E., Roldin, P., Henzing, J. S., Moerman, M., Mihalopoulos, N., Kouvarakis, G., Ždímal, V., Zóková, N., Marinoni, A., Bonasoni, P., and Duchi, R.: Primary versus secondary contributions to particle number concentrations in the European boundary layer, Atmos. Chem. Phys., 11, 12007-12036, doi:10.5194/acp-11-12007-2011, 2011.

Riipinen, I., Sihto, S.-L., Kulmala, M., Arnold, F., Dal Maso, M., Birmili, W., Saarnio, K., Teinilä, K., Kerminen, V.-M., Laaksonen, A., and Lehtinen, K. E. J.: Connections between atmospheric sulphuric acid and new particle formation during QUEST III-IV campaigns in Heidelberg and Hyytiälä, Atmos. Chem. Phys., 7, 1899-1914, doi:10.5194/acp-7-1899-2007, 2007.

Robertson, L., Langner, J., and Engardt, M.: An Eulerian LimitedArea Atmospheric Transport model, J. Appl. Meteorol., 38, 190210, 1999.

Roesler, E. L. and Penner, J. E.: Can global models ignore the chemical composition of aerosols?, Geophys. Res. Lett., 17, L24809, doi:10.1029/2010GL044282, 2010.

Saunders, S. M., Jenkin, M. E., Derwent, R. G., and Pilling, M. J.: Protocol for the development of the Master Chemical Mechanism, MCM v3 (Part A): tropospheric degradation of nonaromatic volatile organic compounds, Atmos. Chem. Phys., 3, 161-180, doi:10.5194/acp-3-161-2003, 2003.

Schaap, M., Timmermans, R. M. A., Roemer, M., Boersen, G. A. C., and Builtjes, P.: The LOTUS-EUROS model: description, validation and latest developments, Int. J. Environ. Poll., 32, 270-290, 2008.

Schlesinger, R. B., Kunzli, N., Hidy, G. M., Gotschi, T., and Jerrett, M.: The health relevance of ambient particulate matter charac- 
teristics: coherence of toxicological and epidemiological inferences, Inhal. Toxicol., 18, 95-125, 2006.

Seinfeld, J. H. and Pandis, S. N.: Atmospheric chemistry and physics, From air pollution to climate change, John Wiley and sons, 1997.

Sihto, S.-L., Kulmala, M., Kerminen, V.-M., Dal Maso, M., Petäjä, T., Riipinen, I., Korhonen, H., Arnold, F., Janson, R., Boy, M., Laaksonen, A., and Lehtinen, K. E. J.: Atmospheric sulphuric acid and aerosol formation: implications from atmospheric measurements for nucleation and early growth mechanisms, Atmos. Chem. Phys., 6, 4079-4091, doi:10.5194/acp-6-4079-2006, 2006.

Simon, H., Bhave, P. V., Swall, J. L., Frank, N. H., and Malm, W. C.: Determining the spatial and seasonal variability in OM/OC ratios across the US using multiple regression, Atmos. Chem. Phys., 11, 2933-2949, doi:10.5194/acp-11-2933-2011, 2011.

Simpson, D.: Long-period modelling of photochemical oxidants in Europe. Model calculations for July 1995, Atmos. Environ. 26A, 1609-1634, 1992.

Simpson, D., Andersson-Skiöld, Y., and Jenkin, M. E.: Updating the chemical scheme for the EMEP MSC-W oxidant model: current status, EMEP MSC-W Note 2/93, 1993.

Simpson, D., Guenther, A., Hewit, C. N., and Steinbrecher, R.: Biogenic emissions in Europe. 1. Estimates and uncertainties, J. Geophys. Res., 100, 22875-22800, 1995.

Simpson, D., Yttri, K., Klimont, Z., Kupiainen, K., Caseiro, A., Gelencsér, A., Pio, C., and Legrand, M.: Modeling Carbonaceous Aerosol over Europe. Analysis of the CARBOSOL and EMEP EC/OC campaigns, J. Geophys. Res., 112, D23S14, doi:10.1029/2006JD008158, 2007.

Simpson, D., Benedictow, A., Berge, H., Bergström, R., Emberson, L. D., Fagerli, H., Flechard, C. R., Hayman, G. D., Gauss, M., Jonson, J. E., Jenkin, M. E., Nyíri, A., Richter, C., Semeena, V. S., Tsyro, S., Tuovinen, J.-P., Valdebenito, Á., and Wind, P.: The EMEP MSC-W chemical transport model - technical description, Atmos. Chem. Phys., 12, 7825-7865, 2012, http://www.atmos-chem-phys.net/12/7825/2012/.

Spracklen, D. V., Pringle, K. J., Carslaw, K. S., Chipperfield, M. P., and Mann, G. W.: A global off-line model of sizeresolved aerosol microphysics: I. Model development and prediction of aerosol properties, Atmos. Chem. Phys., 5, 22272252, doi:10.5194/acp-5-2227-2005, 2005a.

Spracklen, D. V., Pringle, K. J., Carslaw, K. S., Chipperfield, M. P., and Mann, G. W.: A global off-line model of size-resolved aerosol microphysics: II. Identification of key uncertainties, Atmos. Chem. Phys., 5, 3233-3250, doi:10.5194/acp-5-3233-2005, 2005b.

Spracklen, D. V., Carslaw, K. S., Kulmala, M., Kerminen, V.-M., Mann, G. W., and Sihto, S.-L.: The contribution of boundary layer nucleation events to total particle concentrations on regional and global scales, Atmos. Chem. Phys., 6, 5631-5648, doi:10.5194/acp-6-5631-2006, 2006.

Spracklen, D. V., Carslaw, K. S., Merikanto, J., Mann, G. W., Reddington, C. L., Pickering, S., Ogren, J. A., Andrews, E., Baltensperger, U., Weingartner, E., Boy, M., Kulmala, M., Laakso, L., Lihavainen, H., Kivekäs, N., Komppula, M., Mihalopoulos, N., Kouvarakis, G., Jennings, S. G., O’Dowd, C., Birmili, W., Wiedensohler, A., Weller, R., Gras, J., Laj, P., Sellegri, K., Bonn, B., Krejci, R., Laaksonen, A., Hamed, A., Minikin, A., Harri- son, R. M., Talbot, R., and Sun, J.: Explaining global surface aerosol number concentrations in terms of primary emissions and particle formation, Atmos. Chem. Phys., 10, 4775-4793, doi:10.5194/acp-10-4775-2010, 2010.

Stern, R., Builtjes, P., Schaap, M., Timmermans, R., Vautard, R., Hodzic, A., Memmesheimer, M., Feldmann, H., Renner, E., Wolke, R., and Kerschbaumer, A.: A model inter-comparison study focussing on episodes with elevated PM10 concentrations, Atmos. Environ., 42, 4567-4588, doi:10.1016/j.atmosenv.2008.01.068, 2008.

Turpin, B. J., Saxena, P., and Andrews, E.: Measuring and simulating particulate organics in the atmosphere: problems and prospects, Atmos. Environ., 34, 2983-3013, 2000.

Undén, P., Rontu, L., Järvinen, H., Lynch, P., Calvo, J., Cats, G., Cuxart, J., Eerola, K., Fortelius, C., Garcia-Moya, J. A., Jones, C., Lenderlink, G., McDonald, A., McGrath, R., Navascues, B., Woetman Nielsen, N., Ödegaard, V., Rodriguez, E., Rummukainen, M., Room, R., Sattler, K., Hansen Sass, B., Savijärvi, H., Wichers Schreur, B., Sigg, R., The, H., and Tijm, A.: HIRLAM-5 Scientific Documentation, http://www.hirlam. org (last access: 2 February 2015), 2002.

Vehkamäki, H., Kulmala, M., Napari, I., Lehtinen, E. J., Timmreck, C., Noppel, M. and Laaksonen, A.: An improved parameterization for sulphuric acid/water nucleation rates for tropospheric and stratospheric conditions, J. Geophys. Res., 107, 4622, doi:10.1029/2002JD002184, 2002.

Visschedijk, A. J. H., Denier van der Gon, H., Dröge, A. C., Van der Brugh, H., and Kooter, I. M.: A European high resolution and size-differentiated emission inventory for elemental and organic carbon for the year 2005, TNO report, TNO-034-UT-200900688-RPT-ML, 2009.

Whitby, E. and McMurry, P.: Modal aerosol dynamics modeling, Aerosol. Sci. Technol., 27, 673-688, 1997.

WHO: Review of evidence on health aspects of air pollution - REVIHAAP project, Technical Report, available at: http://www.euro.who.int/_data/assets/pdf_file/0004/193108/ REVIHAAP-Final-technical-report-final-version.pdf?ua=1 (last access: 2 February 2015), 2013.

Yu, F. and Luo, G.: Simulation of particle size distribution with a global aerosol model: contribution of nucleation to aerosol and CCN number concentrations, Atmos. Chem. Phys., 9, 76917710, doi:10.5194/acp-9-7691-2009, 2009.

Zhang, L., Gong, S., Padro, J., and Barrie, L.: A size-segregated particle dry deposition scheme for an atmospheric aerosol module, Atmos. Environ., 35, 549-560, 2001.

Zhang, K., O’Donnell, D., Kazil, J., Stier, P., Kinne, S., Lohmann, U., Ferrachat, S., Croft, B., Quaas, J., Wan, H., Rast, S., and Feichter, J.: The global aerosol-climate model ECHAM-HAM, version 2: sensitivity to improvements in process representations, Atmos. Chem. Phys., 12, 8911-8949, doi:10.5194/acp-12-89112012, 2012.

Zhang, X. Cappa, C. D., Jathar, S. H., McVay, R. C., Ensberg, J. J., Kleeman, M. J., andSeinfeld, J. H.: Influence of vapor wall loss in laboratory chambers on yields of secondary organic aerosol, Proc. Natl. Acad. Sci., 111, 5802-5807, doi:10.1073/pnas.1404727111, 2014. 